\title{
Full-Scale Test Program for a Shower Wastewater Recycling System:
}

\section{Technical Evaluation}

by

Richard J. Scholze

John T. Bandy

Donald K. Jamison

James A. Morgan

Vincent J. Ciccone

William P. Gardiner

Ed D. Smith

\section{For Reference}

Not to be taken from this room

A shower wastewater recycling system is investigated for potential military use under conditions of limited water supply. Results are reported for laboratory tests on the proposed system. Parameters measured in the tests include those specified by the Office of the Surgeon General (OTSG) in the Interim Quality Criteria for direct reuse of water as well as several others of concern.

The laboratory test results show that the wastewater recycling system merits further investigation and development. The proposed system is compatible with existing Army facilities and equipment and is portable. Wastewater can be treated to a quality meeting OTSG standards. Several recycles are possible, with 85 percent of the wastewater recoverable for reuse. No harmful contaminants were detected in any of the test samples. 
The contents of this report are not to be used for advertising, publication, or promotional purposes. Citation of trade names does not constitute an official indorsement or approval of the use of such commercial products. The findings of this report are not to be construed as an official Department of the Army position, unless so designated by other authorized documents. 


\section{USER EVALUATION OF REPORT}

REFERENCE: USA-CERL IR N-87/06, FuZZ-ScaZe test Program for a Shower Wastewater Recycling System: Technical Evaluation

Please take a few minutes to answer the questions below, tear out this sheet, and return it to USA-CERL. As a user of this report, your customer comments will provide USACERL with information essential for improving future reports.

1. Does this report satisfy a need? (Comment on purpose, related project, or other area of interest for which report will be used.)

2. How, specifically, is the report being used? (Information source, design data or procedure, management procedure, source of ideas, etc.)

3. Has the information in this report led to any quantitative savings as far as manhours/contract dollars saved, operating costs avoided, efficiencies achieved, etc.? If so, please elaborate.

4. What is your evaluation of this report in the following areas?

a. Presentation:

b. Completeness:

c. Easy to Understand:

d. Easy to Implement:

e. Adequate Reference Material:

f. Relates to Area of Interest:

g. Did the report meet your expectations?

h. Does the report raise unanswered questions? 
i. General Comments. (Indicate what you think should be changed to make this report and future reports of this type more responsive to your needs, more usable, improve readability, etc.)

5. If you would like to be contacted by the personnel who prepared this report to raise specific questions or discuss the topic, please fill in the following information.

Name:

Telephone Number:

Organization Address:

6. Please mail the complete form to:

Department of the Army CONSTRUCTION ENGINEERING RESEARCH LABORATORY ATTN: CERL-IMT

P.O. Box 4005

Champaign, IL 61820 


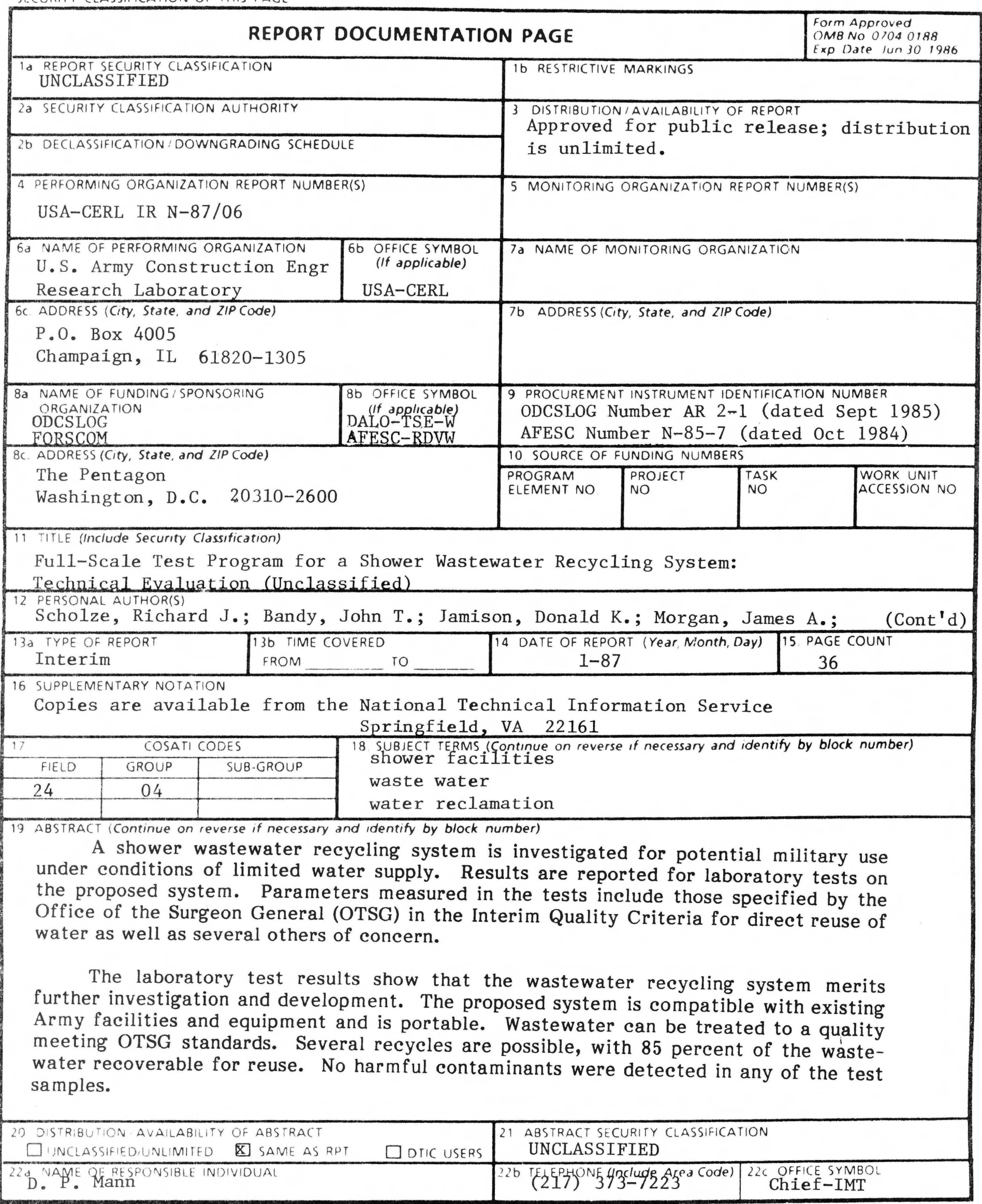


UNCLASSIFIIDD

BLOCK 12 (Cont'd)

Ciccone, Vincent J.; Gardiner, William P.; Smith, Ed D. 


\section{FOREWORD}

This research was conducted for the U.S. Army Troop Support Command (TROSCOM) through the Army Water Office, Office of the Deputy Chief of Staff for Logistics (ODCSLOG), under Order Number AR 2-1 (dated September 1985) and for the U.S. Air Force Engineering and Services Center (AFESC), Tyndall AFB, FL, under Job Order Number N-85-7 (dated October 1984). MAJ Michael Murphy, DALO-TSE-W, and LT Al Rhodes, AFESC-RDVW, were the Technical Monitors.

The investigation was performed by the Environmental Division (EN), U.S. Army Construction Engineering Research Laboratory (USA-CERL). Dr. R. K. Jain is Chief EN.

Appreciation is expressed to the following personnel and agencies for review and comments: Martin Fadden (ODCSLOG), Headquarters, Department of the Army; $W$. Dickinson Burrows and coworkers, U.S. Army Medical Bioengineering Research and Development Laboratory (USAMBRDL); and LTC Roy Miller, CPT Trent Moxley, and Pedro Cunanan, U.S. Army Environmental Hygiene Agency (USAEHA).

COL Norman C. Hintz is Commander and Director of USA-CERL, and Dr. L. R. Shaffer is Technical Director. COL Roy G. Kennington is Commander of AFESC and LTC Lawrence D. Hokanson is Director of AFESC Engineering and Services Laboratory. 
$\begin{array}{ll}\text { DD FORM } 1473 & 1 \\ \text { FOREWORD } & 3 \\ \text { LIST OF TABLES AND FIGURES } & 5\end{array}$

$1 \quad \begin{aligned} & \text { INTRODUCTION } \ldots \ldots \ldots \ldots \ldots \ldots \ldots \ldots \ldots \ldots \ldots \ldots \ldots \ldots \ldots \ldots \ldots \ldots \ldots \ldots \ldots \ldots \\ & \text { Background }\end{aligned}$

Objective

Approach

Scope

Mode of Technology Transfer

2 TEST DESIGN AND PROCEDURES

System Design and Equipment

Bathing Procedures

Wastewater Treatment Operations

Recycling Procedure

Water Quality Sampling and Testing

3 RESULTS AND ANALYSIS

19

Test Data

Operations Analysis

Analysis of Water Quality Parameters

4 CONCLUSIONS AND RECOMMENDATIONS

34

APPENDIX: Shower Test Consent Form $\quad 35$

$\begin{array}{ll}\text { LIST OF ABBREVIATIONS } & 36\end{array}$

DISTRIBUTION 


\section{TABLES}

1 Record of Shower Wastewater Treatment

2 Interim Water Quality Standards for Direct Reuse of Shower Wastewater

$3 \quad$ Shower Water Sampling and Testing Schedule

4 Measured Parameters in Wastewater, Settled, and Filtered Water--Batch 1

5 Measured Parameters in Wastewater, Settled, and Filtered Water--Batch 2, Cycles 1 Through 6

6 Measured Parameters in Wastewater, Settled, and Filtered Water--Batch 2, Cycles 7 Through 11

$7 \quad$ Bacteriological Report

\section{FIGURES}

1 Shower Wastewater Recycling System Design

$2 \quad$ Shower Stalls

3 Shower Wastewater Collection Tank

4 Addition of Polyelectrolyte to Treatment and Settling Tank

$6 \quad$ Turbidity

$7 \quad$ Mean $\mathrm{pH}$

$8 \quad$ Hardness

$9 \quad$ Linear Alkyl Sulfonate

10 Total Dissolved Solids

11 Chemical Oxygen Demand

12 Total Organic Carbon 



\section{FULL-SCALE TEST PROGRAM FOR A SHOWER WASTEWATER RECYCLING SYSTEM: TECIINICAL EVAIUATION}

\section{INTRODUCTION}

\section{Background}

Since World War I, U.S. military operations have traditionally been in areas with plentiful fresh water, such as Europe and Southeast Asia. Thus, little attention has been given to availability of water supplies and sources or to the need to regulate water use under field conditions. However, recent attention has been directed toward water resource management to insure the Army's readiness should deployment to arid regions ever become necessary. Water conservation, recycling, and reuse are some of the water management options being examined.

Providing water to a military force operating in hot desert regions or other watershort areas would be a major logistics effort. Two major water demands are for laundries and showers. Both activities offer opportunities for recycling which can save large amounts of water--particularly in water-short areas. This savings in water may permit troops and vehicles otherwise committed to water supply to be used elsewhere in the Theater of Operations. Additional savings could accrue from reduced fuel and other costs associated with water transport.

The concept of recycling wastewater from showers and laundries with a simple batch system was first described in 1981. Development of laundry recycling has progressed through laboratory and field exercises as reported earlier. ${ }^{2}$ To evaluate the feasibility of a shower recycling system, similar laboratory and field tests are needed.

\section{Objective}

The objectives of this work are to develop, test, and refine a shower recycling system for Army-wide use in any Theater of Operations.

The specific objectives of this study were to: system.

1. Conduct laboratory tests on a full-scale prototype shower wastewater recycling

2. Confirm that wastewater effluent from the portable bath unit used (M-1958) can be treated by a combination of coagulation, filtration, and disinfection techniques to

\footnotetext{
'Mathematical Modeling for Evaluation of Field Water Supply Alternatives (Arid and Semi-Arid Regions) (Virginia Military Institute Research Laboratory, January 1981 ). J. T. Bandy, et al., Development of a Field Laundry Wastewater Recycling System, Technical Report N-86/08/ADA169585(U.S. Army Construction Engineering Research Laboratory [USA-CERL], 1986); R. J. Scholze, et al., Testing of a Field Laundry. Wastewater Recycling System, Technical Report N-87/01/A174744 (USA-CERL, 1986).
} 
produce water meeting Office of the Surgeon General (OTSG) interim quality criteria for direct laundry or shower reuse; or, to modify the treatment process as necessary to meet these criteria.

3. Evaluate the suitability and compatibility of the proposed wastewater treatment equipment and operating procedures when employed with the standard Army bath units or with comparable Army Facilities Component System (AFCS) structures. ${ }^{3}$

4. Determine the number of reuse treatment cycles that can be performed while continuing to meet the OTSG interim quality criteria.

5. Determine the amounts of chemicals (e.g., powdered carbon, polyelectrolytes, diatomaceous earth, chlorine) required in the wastewater treatment process and the extent to which the powdered activated carbon can be reused.

6. Determine the reliability of the treatment process by replicating the tests several times.

7. Perform chemical analysis of field shower wastewater to identify and quantify contaminants that may have potential health implications.

8. Perform chemical analysis of the renovated wastewater to compare the quality of the water produced with the standards for shower water prescribed by OTSG and other recognized health authorities.

\section{Approach}

A prototype shower wastewater recycling system was laboratory-tested at the Virginia Military Institute (VMI), Lexington, VA, to verify the system's effectiveness in treating shower wastewater for reuse. A battery of chemical and physical water quality tests were performed and compared with OTSG interim quality criteria for direct reuse of reclaimed wastewater in military field showers. Trace organic analyses were also performed.

\section{Scope}

The information in this report represents early stages in the development of a shower wastewater recycling system. Additional work is expected to further confirm the safety of the concept, and an operational evaluation is in progress. Future Technical Reports and a review by the National Research Council will emphasize health effects.

\section{Mode of Technology Transfer}

When the shower wastewater recycling system has been fully developed, tested, and proven safe and effective, this technology may be incorporated into Field Manual (FM) 10-280, Field Laundry Clothing Exchange and Bath Operations, and/or new guidance may be developed to enable its use Army-wide.

\footnotetext{
${ }^{3}$ Technical Manual (TM) 5-820-2, Army Facilities Components System (Headquarters, Department of the Army [HQDA], September 1977).
} 


\section{TEST DESIGN AND PROCEDURES}

For the testing at VMI (Virginia Military Institute), major hardware components installed were: six prefabricated shower stalls, a commercial hot water heater, and a 500-gal collapsible water tank. Key equipment items for the shower wastewater treatment were a U.S. Army Water Pollution Abatement $\mathrm{Kit}^{4}$ and a $420 \mathrm{-gal} / \mathrm{hr}$ diatomite filter. The treatment process involved manual addition of sulfuric acid, high quality powdered activated carbon (PAC), and both cationic and anionic polyelectrolytes (Army inventory) to each $500 \mathrm{gal}$ of collected wastewater. Sulfuric acid was used to adjust the $\mathrm{pH}$ of the wastewater and thereby enhance the formation of flocculant, containing carbon and dirt to accelerate settling of particles and adsorbed contaminants. Filtration by a diatomaceous earth filter and disinfection with chlorine were the last steps in the treatment process prior to reuse.

\section{System Design and Equipment}

Figure $1^{*}$ is a schematic diagram of the system design used in the test. The equipment assembly for the test program used hard piping and commercial power instead of standard military hoses and an engine-driven electric generator set.

Freshwater Tank (FWT)

The FWT was an open-top, 500-gal capacity cylindrical metal tank. The tank temporarily stored potable and reclaimed water used for the showers (Figure 1).

\section{Water Heater}

The electric 4500-W water heater was a 42-gal, glass-lined unit. Stored shower water from the FWT was pumped through the heater to the shower stalls at $160^{\circ} \mathrm{F}$ (Figures 1 and 2).

\section{Showers}

Five commercial prefabricated metal shower stalls were erected on the upper level in the laboratory (Figure 2). Four shower stalls were plumbed for hot and cold recycled water, and one for only potable water. Each shower was equipped with a shower head rated at $2 \mathrm{gal} / \mathrm{min}(\mathrm{gpm})$. Drains for the four recycled water showers were plumbed with polyvinyl chloride (PVC) piping to collect all wastewater for discharge in to the collection tank (CT). In addition, a bypass was added to the building drain system to divert water used in cleaning the showers to the sanitary sewer system rather than to the collection tank. The one potable water shower was similarly plumbed, with the exception that hot and cold feedwater connections were made to the building water supply system and the drain was connected to a building sanitary waste line.

\footnotetext{
${ }^{4}$ Operator and Organizational Maintenance Manual, Laundry Wastewater Treatment Kit, NSN 4610-01-023-4536 (System Division of MET-PRO Corp., Harleysville, PA, October 1977).

*Figures and tables are located at the end of each chapter.
} 


\section{Collection Tank}

The CT was a graduated open-top, 500-gal polyethylene cylindrical tank and was used to collect shower wastewater before treatment (Figures 1 and 3).

Treatment and Settling Tank (TST)

The TST was a 500-gal collapsible fabric tank complete with staves, pegs, spreaders, and ground cloth. Wastewater collected in the CT was pumped to the TST, where sulfuric acid, polymers, and PAC were added and mixed. The flocculation and settling steps of the treatment process occurred in the TST (Figures 1 and 4).

\section{Diatomaceous Earth Precoat Tank (DE Precoat Tank)}

The DE precoat tank was an open-top, 50-gal graduated polyethylene cylindrical tank (Figures 1 and 5). This tank was used to prepare a diatomite slurry needed to precoat the septa in the diatomaceous earth filter.

\section{Diatomaceous Earth Filter (DE Filter)}

The DE filter was a 420-gal/hr diatomaceous earth filter currently part of the 420 $\mathrm{gal} / \mathrm{hr}$ Water Purification Set (ERDLATOR). It was equipped with an integral 110-V electrically driven pump and provided the second step in the treatment process (Figures 1 and 5).

\section{Holding Tank (HT)}

The HT was an open-top, 250-gal graduated polyethylene cylindrical tank (Figure 5) used to collect and hold the filtrate from the DE filter. The reclaimed wastewater recycled for subsequent showers was disinfected here by the manual addition of calcium hypochlorite.

\section{Bathing Procedures}

Shower wastewater was collected from the bathing facility installed at the laboratory especially for this test. Bathers were students and faculty members who were invited to participate in the test during the summer school session. Every participant showered after having engaged in some strenuous physical activity, such as jogging and tennis. This activity was required of all bathers so that the shower wastewater would somewhat approximate that from physically active soldiers or airmen bathing in the field. However, it should be noted that soldiers and/or airmen will become dirtier than the personnel who participated in the laboratory study. Furthermore, soldiers are expected to take only one shower per week under field conditions, which must be taken into account for realistic full-scale testing. During the test period, a total of 860 showers were taken, each using an average $10.6 \mathrm{gal}$ of water. Bathers were permitted to use their own choice of soap and shampoo, a condition expected to exist in a Theater of Operations.

To generate the initial 500 gal of shower wastewater needed for each "batch," water from the Lexington, VA, municipal water supply system was used in the showers. Thereafter, bathers took showers using the treated recycled wastewater. (Note: each shower with recycled water taken by each participant was immediately followed by one using potable water from the VMI water distribution system.) 
All bathers were advised of the test's purpose and the procedures to be followed. Only those who signed a consent form (appendix) were selected to participate.

Showers were cleaned and disinfected when inspections revealed a noticeable accumulation of soap and dirt. Water used for cleaning was discharged into the sanitary line and not permitted to drain into the wastewater CT. This procedure also parallels field conditions.

\section{Wastewater Treatment Operations}

After collecting 500 gal of shower wastewater and prior to treatment, bench-scale jar tests were performed, to determine the amount of acid, PAC (HYDRODARCO brand), and polymer needed to treat the wastewater effectively. These tests were performed on wastewater and without the benefit of any resuspended carbon from the TST. What effect, if any, this procedure had on determining the amount of PAC to add during each treatment cycle was not evaluated. It should be noted that the PAC used was highquality; use of a lower quality may require additional amounts.

Measured amounts of PAC and sulfuric acid were added to the TST as wastewater was being transferred from the CT. Then, by closing valve V-5A and operating pump P-2, the wastewater and chemicals were recirculated for $20 \mathrm{~min}$ to achieve thorough mixing. After the acid and PAC were mixed, $75 \mathrm{~mL}$ of Type-I polymer (CAT-FLOC brand cationic) was diluted with $750 \mathrm{~mL}$ fresh water, half of which was added to 1 gal of TST water to provide a polymer solution and then added to the TST. This step was repeated with the remaining Type-i polymer solution and the contents of the tank were recirculated again for approximately $5 \mathrm{~min}$.

During this time interval, two $1000-\mathrm{mL}$ beakers were filled with fresh water, $1 / 2 \mathrm{~g}$ of Type-II polymer (powdered) was added to each (sprinkled to avoid clumping), and the liquid in the beakers was agitated frequently to mix the polymer thoroughly. The Type-II polymer (anionic) solution was added to the TST and the tank contents were stirred manually for about $5 \mathrm{~min}$ or until large-diameter floc appeared. The contents of the TST were then allowed to settle for approximately $25 \mathrm{~min}$ or to the point at which the water reached acceptable clarity (tip of mixing paddle could be seen clearly). After settling was complete, 16 water samples were taken from the TST using 500-mL biochemical oxygen demand (BOD) bottles and then divided into fractions for chemical analyses.

Diatomaceous earth filtration of the TST supernatant was the next step in the treatment process. The DE filter septa were precoated with a slurry consisting of $0.8 \mathrm{lb}$ diatomite in $15 \mathrm{gal}$ of water. Precoating was done using pump P-3 which is integral to the filter and by closing valve $V-7$ and opening valve $V-8$. The slurry was recirculated for over $5 \mathrm{~min}$ to fully coat the septa in the DE filter. Valves were then reset ( $\mathrm{V}-7$ to open, $V-8$ to close, and the three-way valve on the DE filter to "filter") and the filtering of the supernatant in the TST was begun. To avoid pumping any accumulated sludge from the bottom of the TST, a 90-degree elbow was attached to the end of the 1-1/2-in. tank drain outlet and the drop in the tank's water level was observed to avoid overpumping. Filtration backwash was initiated when the pressure exceeded 40 psig. Variation in the number of gallons filtered was due to the wastewater quality.

The filtered discharge from the DE filter was collected in the 500-gal HT. Two samples were collected in 500-mL BOD bottles for chemical analysis after 200 to $300 \mathrm{gal}$ were filtered; additional $500-\mathrm{mL}$ samples were collected for turbidity analysis after 
about $400 \mathrm{gal}$ had been filtered. At the midpoint of the filtering process, a $4-\mathrm{oz}$ sample of filtrate was collected in a NASCO sodium thiosulfate Whirl-Pak bag for testing total organic carbon (TOC) and coliform levels.

The final step of the treatment process was disinfection of the filtered water. Approximately $15 \mathrm{~g}$ of calcium hypochlorite was added manually to provide an acceptable level of free residual chlorine $(5.5 \mathrm{ppm})$ in the treated water (approximately $500 \mathrm{gal}$ ).

\section{Recycling Procedure}

The treatment process summarized above describes a typical cycle in the treatment of a 500-gal batch of shower wastewater. Table 1 lists specific details of the treatment during each recycling sequence for batches 1 and 2 . Batch 1 was recycled eight times and batch 2 eleven times.

The treatment procedure was adjusted to improve flocculant formation and the settlement rate. The changes were reflected in the amount of sulfuric acid added to adjust the $\mathrm{pH}$ of the wastewater. Also, the amount of PAC was varied to determine if reductions could be made without degrading the treatment process. The adjustments in amounts of acid and PAC were based on results of the jar tests conducted on wastewater samples taken at the beginning of each cycle.

The filterability of the supernatant in the TST was reflected in the number of times the DE filter was backwashed. In general, the frequency of backwashing was greater during the initial cycles of a batch when carbon sludge was not available for resuspension.

Filterability was also reflected in the amount of filtered water obtained from each treatment cycle. The amounts recorded in Table 1 generally decrease in the later cycles, which reflects the retention of water in the sludge as it built up from one cycle to the next.

\section{Water Quality Sampling and Testing}

To assess the effectiveness of the batch treatment reclamation process, samples of shower wastewater, settled water, and filtered water were taken during each cycle and tested for selected quality parameters using standard testing methods. Water produced during each treatment cycle was stirred vigorously before sampling to obtain a homogeneous mixture. The grab sample was then divided into four aliquots which represented four extracts taken at random from the homogeneous mixture. From this sample, 1 to 4 measurements were performed and averaged. These procedures were used so that any variations observed in the replicate measures were due to random (chance) variations within the original mixture and in the analytical techniques.

Although the interim water quality standards for the direct reuse of shower wastewater proposed by OTSG sets limits on only $\mathrm{pH}$, turbidity, and residual chlorine (Table 2), several more parameters were evaluated in this study. These tests were run based on the schedule shown in Table 3 and using the following standard procedures. 
Alkalinity

The methyl orange indicator method was used to determine alkalinity.

Total Dissolved Solids (TDS) dried.

To determine TDS, the amount of residue was weighed after a sample was ovenLinear Alkyl Sulfonates (LAS) method.

A Hach DR 3 meter was used to measure the amount of LAS by the crystal violet Total Organic Carbon (TOC)

Samples were analyzed for TOC content by Commonwealth Laboratories in Richmond, VA, using a Beckman Total Organic Carbon Analyzer, Model 915.

Sulfate

The Hach SulfaVer 4 Sulfate Reagent was used to measure sulfate content by the turbidimetric method.

Turbidity

A Hach Laboratory Turbidimeter, Model 2100A, was used to measure turbidity.

pH

A Photovolt $\mathrm{pH}$ meter was used to measure $\mathrm{pH}$. The meter was standardized several times each work day with $\mathrm{pH}$ buffer.

\section{Total Hardness}

The EDTA titrimetric method with Eriochrome Black T as indicator, Hach Standard HexaVer as titrant, and ammonium hydroxide solution as buffer was used to determine the total hardness.

Free Residual Chlorine

A Helige Comparator and N,N-diethyl-p-phenylenediamine (DPD) tablets were used to determine the amount of free residual chlorine.

Total Coliforms

Cold pack samples were collected for laboratory analysis to determine the presence of total coliforms. Analyses were performed by Commonwealth Laboratories of Richmond, VA. 
Chemical Oxygen Demand (COD)

The dichromate reflex method was used to determine chemical oxygen demand.

\section{Trace Organics}

Gas chromatographic/mass spectrometric (GC/MS) analyses were performed in electron impact (EI) mode at $70 \mathrm{eV}$ with a Hewlett-Packard 5985B-RTE VI system (data base of 70,000 mass spectra) that had a $25-\mathrm{m}$ fused silica DB-5 capillary column interfaced directly to the source. Tests were conducted by the Laboratory Research Branch, U.S. Army Medical Bioengineering Research and Development Laboratory, Fort Detrick, MD. 


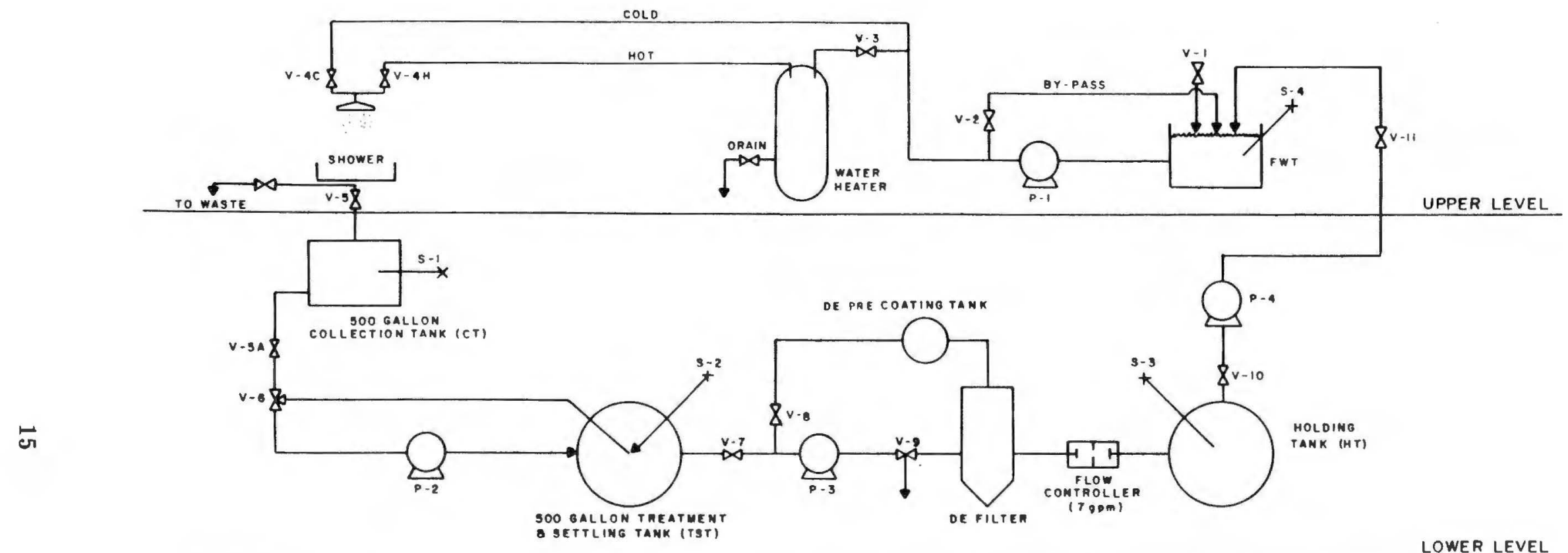

LOWER LEVEL

\section{VALVES $\bowtie$}

$V$ - I FWT CHARGE

$\checkmark$ - 2 WASHER FEEDWATER BY-PASS

$\checkmark-3$ HEATER FEED

V- 4H/V-4C HOT/COLD WATER MIX

V. 5 WASHER DISCHARGE (INTEGRAL)

$\checkmark$-5A WASTEWATER TRANSFER

V-6 RECIRCULATION /TRANSFER THREE - WAY

$V-7$ TST THREE-WAY

$\checkmark$ - PRE DE COATING TANK

V-9 FILTRATION/WASTE

$\checkmark-10$ HOLDING TANK

$V-I I$ FWT/RECYCLE FEED

\section{SAMPLING POINTS $x$}

S-I COLLECTION TANK

S -2 TREATMENT/SETTLING TANK

S- 3 HOLOING TANK (DISINFECTION)

S-4 FRESH WATER TANK

\section{PUMPS}

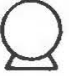

P- 1 FEEDWATER

P- 2 TRANSFER/RECIRCULATION

P-3 DE FILTER

P-4 FWT/RECYCLE TRANSFER

Pigure 1. Shower wastewater recycling system design. 


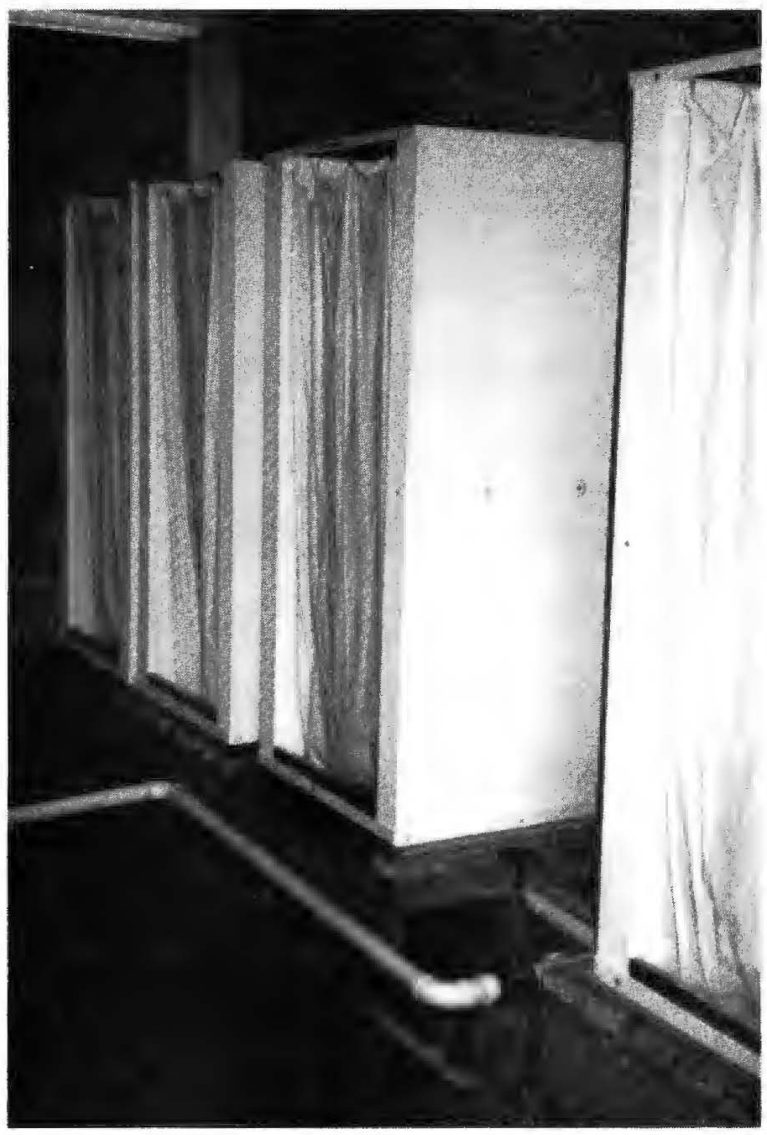

Figure 2. Shower stalls.

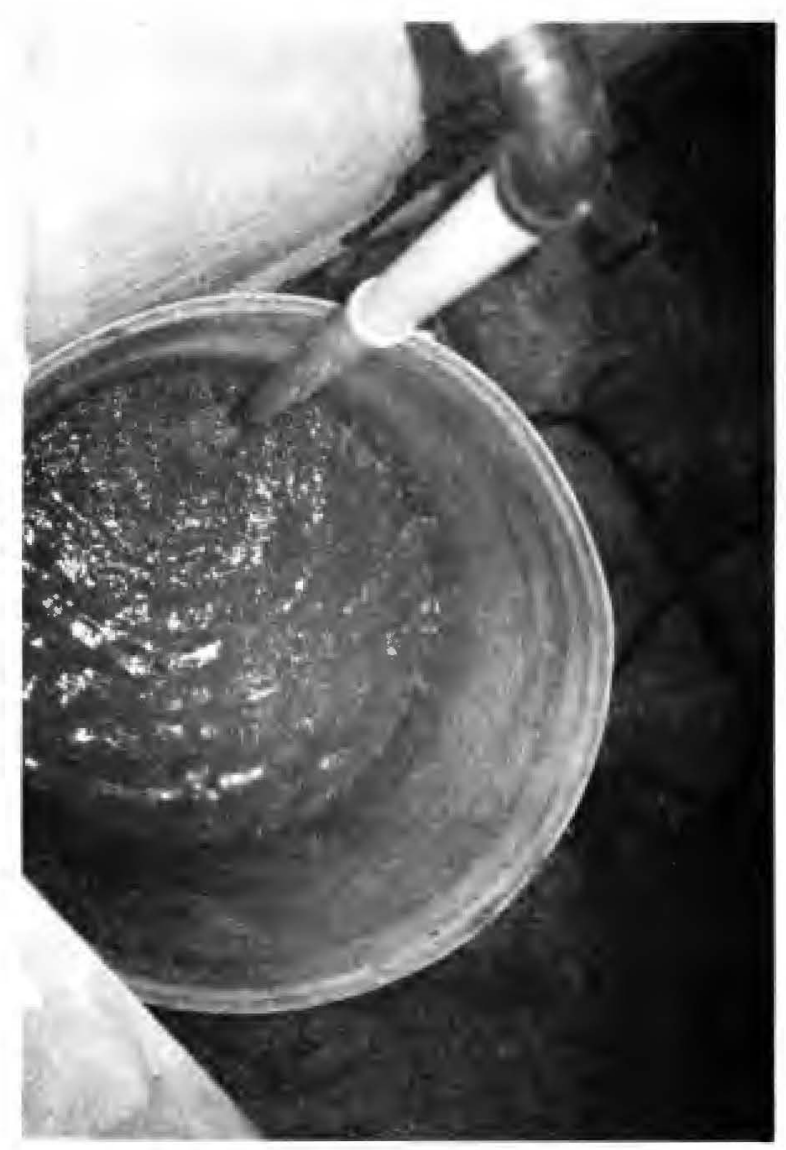

Figure 3. Shower wastewater collection tank.

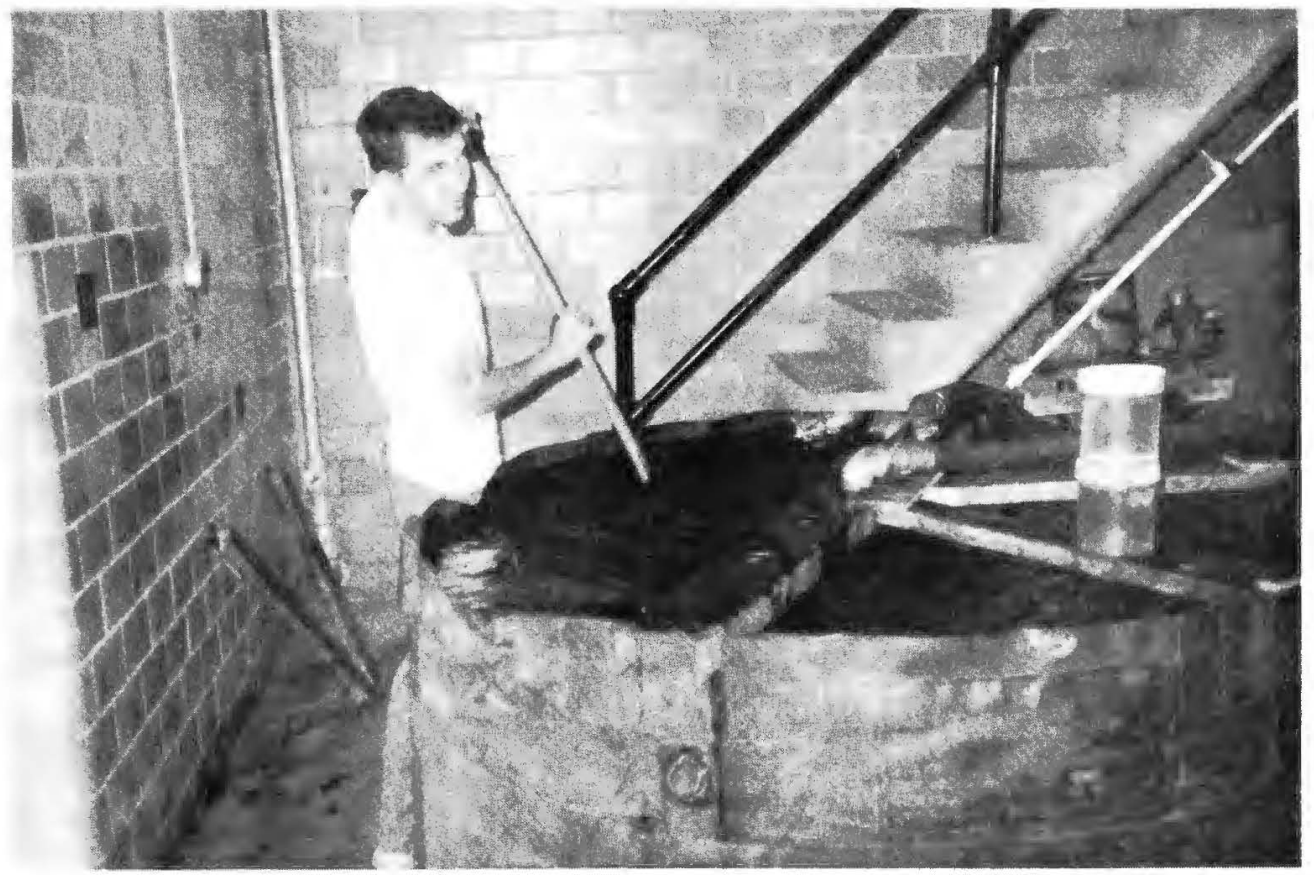

Figure 4. Addition of polyelectrolyte to treatment and settling tank. 


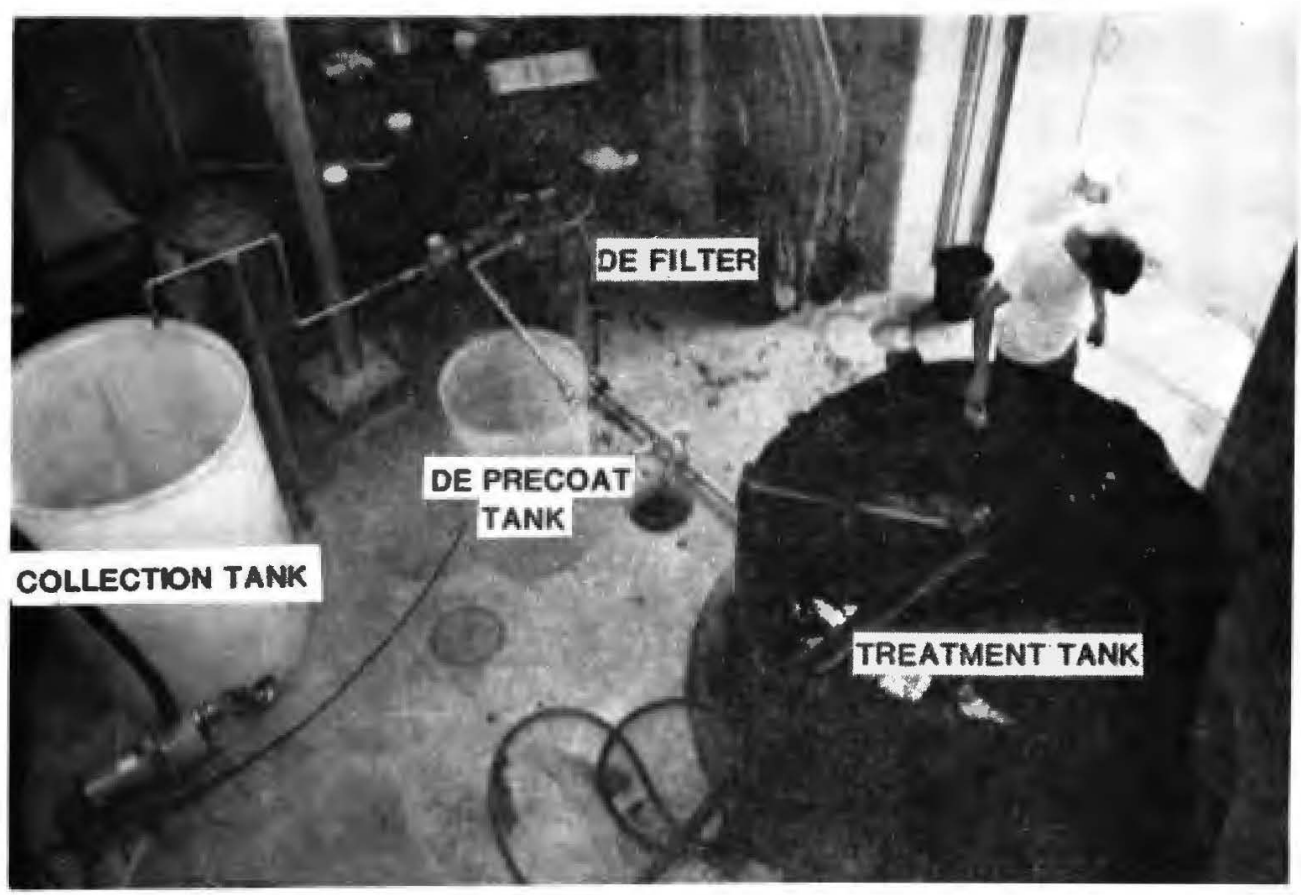

Figure 5. Installed shower wastewater treatment equipment.

Table 1

Record of Shower Wastewater Treatment

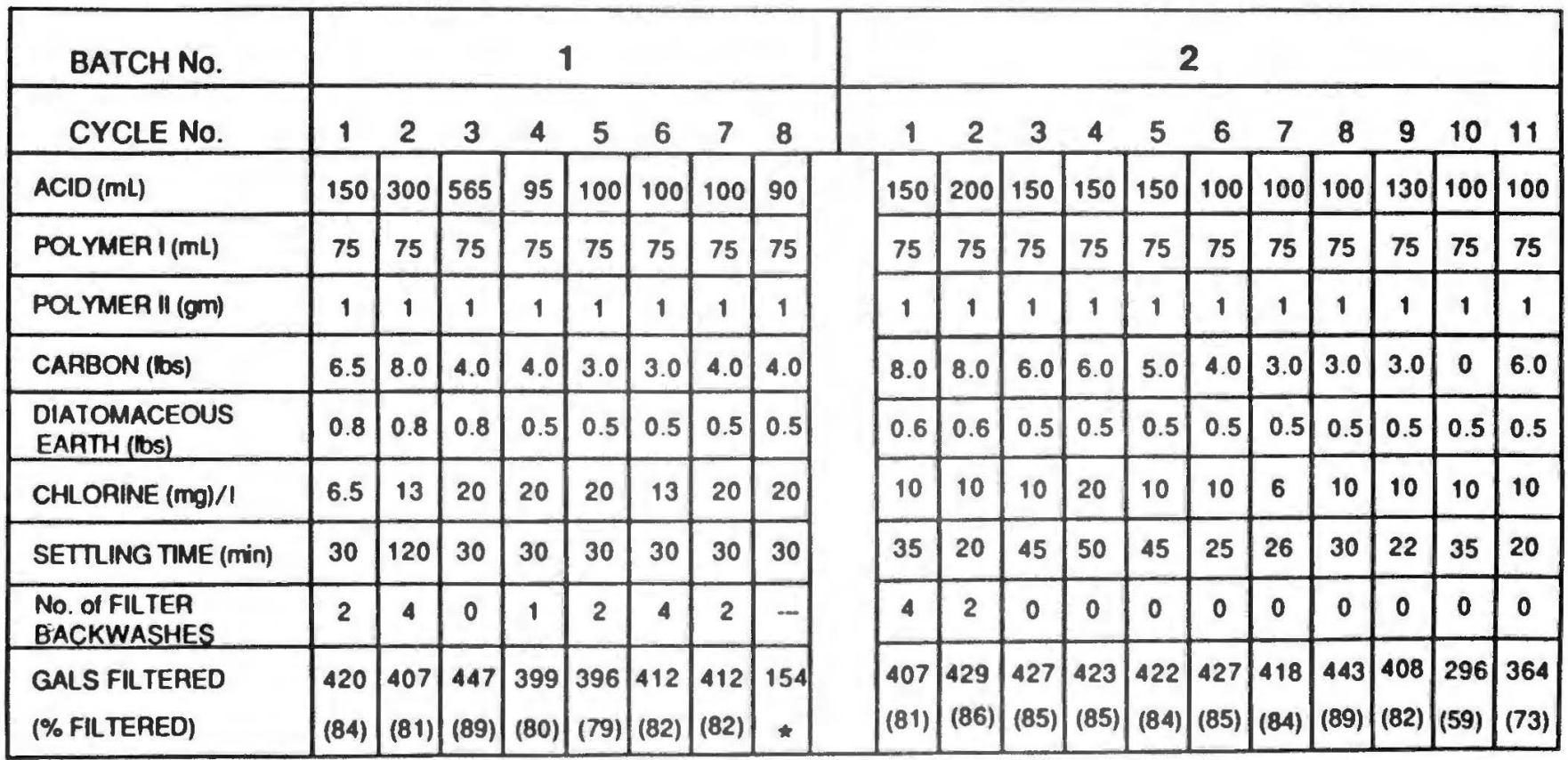

* INCOMPLETE 
Table 2

Interim Water Quality Standards for Direct Reuse of Shower Wastewater*

Parameter

Limits

$\mathrm{pH}$

Turbidity

Free available chlorine

Soap hardness
$6.5-7.5$

$<1$ turbidity unit desirable $<5$ turbidity unit permissible $5 \mathrm{mg} / \mathrm{L}>20^{\circ} \mathrm{C}$ $10 \mathrm{mg} / \mathrm{L}<20^{\circ} \mathrm{C}$ Adequate detergency

*Source: Letter, Department of the Army, Office of the Surgeon General (DASG-PSPE), Subject: Interim Water Quality Criteria for Shower and Laundry Reuse/Recycling (30 October 1980).

Table 3

Shower Water Sampling and Testing Schedule

\begin{tabular}{lccccc}
\hline & $\begin{array}{c}\text { Source } \\
\text { Water }\end{array}$ & $\begin{array}{c}\text { Waste- } \\
\text { water }\end{array}$ & $\begin{array}{c}\text { Settled } \\
\text { Water }\end{array}$ & $\begin{array}{c}\text { Filtered } \\
\text { Water }\end{array}$ & $\begin{array}{c}\text { Disinfected } \\
\text { Water }\end{array}$ \\
\hline Alkalinity & $\mathrm{X}$ & & & $\mathrm{X}$ & \\
Total Dissolved Solids & $\mathrm{X}$ & & & $\mathrm{X}$ & \\
Total hardness & $\mathrm{X}$ & $\mathrm{X}$ & $\mathrm{X}$ & \\
Total Organic Carbon & $\mathrm{X}$ & $\mathrm{X}$ & $\mathrm{X}$ & $\mathrm{X}$ & \\
pH & $\mathrm{X}$ & $\mathrm{X}$ & $\mathrm{X}$ & $\mathrm{X}$ & $\mathrm{X}$ \\
Linear alkyl sulfonate & $\mathrm{X}$ & $\mathrm{X}$ & $\mathrm{X}$ & $\mathrm{X}$ \\
Turbidity & $\mathrm{X}$ & $\mathrm{X}$ & $\mathrm{X}$ & $\mathrm{X}$ & $\mathrm{X}$ \\
Chemical Oxygen Demand & $\mathrm{X}$ & & $\mathrm{X}$ \\
Total Coliforms & $\mathrm{X}$ & $\mathrm{X}$ & & $\mathrm{X}$ \\
Free residual chlorine & $\mathrm{X}$ & $\mathrm{X}$ & & $\mathrm{X}$ & \\
Trace organics & & & & & \\
Sulfate & & & &
\end{tabular}




\section{RESULTS AND ANALYSIS}

\section{Test Data}

Tables 4 through 7 present the data compiled from the measurement of various water quality parameters for each treatment cycle of both batches. Up to four replicate measures of the selected parameters were used for the samples of wastewater effluent, settled water, and filtered water identified in Tables 4 through 6.

Figures 6 through 13 show variations in mean measures for each water quality parameter for effluent and settled water (e.g., concentrations, turbidity units, or $\mathrm{pH}$ units) for each treatment cycle of batches 1 and 2 .

\section{Operations Analysis}

Two batches of wastewater were recycled, one for eight cycles and the second for 11 cycles. The first batch was terminated at the eighth cycle because of a 2-day period when bathers and test operators were not available. The second batch was terminated due to the start of fall classes.

Overall, wastewater treatment operations were satisfactory from start to finish. On one occasion, too much acid was inadvertently added to the wastewater in cycle 3 of batch 1. To correct this problem, it was necessary to add soda ash to raise the $\mathrm{pH}$ to approximately 7.0. Depressing the $\mathrm{pH}$ in other treatment cycles required the addition of between 90 and $150 \mathrm{~mL}$ of sulfuric acid. The chemicals were adjusted for individual cycles based on the results of jar tests.

The amount of PAC added in the treatment process was also adjusted. The highest dosages $(8 \mathrm{lb} / 500 \mathrm{gal})$ were added in the first two treatment cycles of a given batch and then gradually reduced because of the availability of carbon-laden sludge resuspended in subsequent cycles. It was determined that a gradual reduction in carbon from 8 to 3 $\mathrm{lb} / 500 \mathrm{gal}$ was possible without noticeable effect on the clarity of the settled water because residual carbon from earlier treatment cycles remained available to further enhance adsorption and flocculant formation. Whenever the flocculant's settling properties were inadequate, particles tended to remain in suspension and were carried over onto the diatomite filter. Flocculant carryover resulted in shorter filter runs and more frequent backwashing in any one treatment cycle.

In an attempt to reduce the number of filter backwashes experienced in the first two treatment cycles of a new batch, the amount of carbon was increased to $8 \mathrm{lb}$ rather than continue with the $6.5 \mathrm{lb}$ used during the laundry wastewater recycling tests. This adjustment did not produce the desired results as indicated by the number of backwashes shown in Table 1.

A small amount of water that was always lost during each recycling sequence was replaced with make-up water. Water which was not recoverable included that (1) remaining on bathers, (2) used to backwash the filter, and (3) in the concentrated carbon sludge accumulated in the treatment and settling tank. However, water in the carbon sludge after each cycle was not lost until the sludge was discarded at the end of a batch. Approximately 85 percent of the wastewater collected was recovered for recycling during the entire test period with 15 percent makeup water required. 
In the previous tests on laundry wastewater recycling, the PAC and polymer-I were added after the wastewater had been transferred to the TST and the solution was mixed by a combination of recirculating the tank contents with a pump and manual stirring with a paddle. However, for the shower test, the procedure for adding and mixing the chemicals in the TST was changed. PAC, acid, and polymer-I were added in two increments to the TST--the first after $200 \mathrm{gal}$ of wastewater were transferred and the second after another $200 \mathrm{gal}$ were transferred. Complete mixing was achieved by recirculating $\mathrm{TST}$ contents with a pump for $30 \mathrm{~min}$. In this study, the suction hose was positioned at the center of the tank with the discharge hose at the tank periphery so that the contents would receive a tangential motion. This technique proved both effective and labor-saving.

\section{Analysis of Water Quality Parameters}

This analysis covered the data collected for water quality parameters identified in the OTSG Interim Water Quality Standards for the Direct Use of Shower Wastewater (Table 2) and for the additional parameters described in Chapter 2. Overall, the data support the effectiveness of PAC treatment in removing soap, odors, and trace organics from shower wastewater.

\section{Turbidity}

For recycled shower water, the turbidity criteria specified that less than 1 nephelometric turbidity unit (NTU) was desirable, but up to 5 NTU was permissible. In this test, the permissible standard of less than 5 NTU was achieved in 100 percent of the cycles. In 84 percent of the cycles, the desirable standard of less than 1 NTU was achieved. At no time did the turbidity of the filtered water exceed 2 NTU.

Coagulation and settling as the first step in the treatment process reduced wastewater turbidity on average from about 350 NTU to less than 10 NTU. The next treatment step involving filtration of the settled water further reduced the turbidity level to 1 to 2 NTU as Figure 6 shows. On average, the two-step treatment process produced a 99 percent reduction in turbidity.

pH

The recycled water $\mathrm{pH}$ (Figure 7) was generally below the range of 6.5 to 7.5 specified by OTSG, although it averaged about 6.0. Adjustments could have easily been made to raise the $\mathrm{pH}$ to the prescribed range by adding a small amount of soda ash. Another option that was not tested would have been to reduce the amount of acid.

\section{Hardness}

Hardness was measured based on the latherability of soap in the water. As indicated by the data plotted in Figure 8, hardness of the filtered water generally increased with each treatment cycle in both batch 1 and batch 2 .

Water is considered "hard" when hardness reaches a level of about $300 \mathrm{ppm}$, which is approximately two times the hardness of the source water used in this test. However, no bathers complained that they could not obtain a satisfactory lather from soap or shampoo. It is notable here that, in absence of other indicators signaling the maximum number of treatment cycles, this parameter could be used. That is, water should be discarded when it reaches a hardness that prevents lather formation. 


\section{Free Residual Chlorine}

Free residual chlorine was measured using a color comparator and was consistently below $1 \mathrm{ppm}$ regardless of the amount of calcium hypochlorite added to the filtered water. The reasons for such low readings are not explainable, but are possibly due to improper test procedures. Nevertheless, an indication that the filtered water was adequately disinfected was the total absence of coliforms in all treated water samples, as shown in Table 7 .

\section{Linear Alkyl Sulfonate (LAS)}

LAS was measured to determine how well the treatment process removed soaps and detergents. As Figure 9 shows, the LAS averaged about $0.8 \mathrm{ppm}$ in the wastewater and was reduced to about $0.04 \mathrm{ppm}$ in the disinfected water. Furthermore, no significant increase in LAS was observed when the carbon dosage was decreased.

\section{Total Dissolved Solids (TDS)}

As expected, TDS levels in the filtered water generally increased with each treatment cycle. This buildup was believed to be primarily due to the salt in perspiration that was removed during bathing, the addition of sulfuric acid, and the salt from soap.

The plot of TDS (Figure 10) closely resembles that of hardness (Figure 8). Both parameters indicate latherability of soap in a water. Again, despite these increases in hardness and TDS, no bather indicated a problem generating suds.

The rapid rise in TDS associated with cycles 2 and 3 of both batches (Figure 10) can be attributed to the larger-than-normal amount of sulfuric acid used in the treatment during those cycles.

\section{Chemical Oxygen Demand (COD)}

Tests for COD were conducted instead of the more time-consuming test for biochemical oxygen demand (BOD). As Figure 11 shows, the measured values reflect wide variations in the wastewater COD. On the other hand, COD values plotted for the settled water averaged less than that of the source water. This result can be considered an indication of treatment process ef fectiveness over a wide range in COD.

\section{Total Organic Carbon (TOC)}

Figure 12 shows a reduction in TOC levels between the wastewater and filtered water--another indication of the batch treatment process effectiveness. Although a gradual increase in TOC was observed in filtered water for the later cycles, these concentrations did not present a problem.

\section{Alkalinity}

Alkalinity levels in filtered water tended to decrease with each treatment cycle (Figure 13). This trend implies that there is a potential for gradually reducing the amount of acid as the wastewater goes through additional treatment cycles. Data obtained during these tests indicate that about $150 \mathrm{~mL}$ of sulfuric acid can be used for the first five cycles; and thereafter, this amount can be reduced to $100 \mathrm{~mL}$. 


\section{Organics}

The U.S. Army Medical Bioengineering Research and Development Laboratory analyzed the treated water samples for trace organics before and after chlorination using GC/MS equipment. The following findings were reported: 5

For batch one, each of the three samples collected at recycle 1 , recycle 4 , and recycle 8 was analyzed and the results compared with that of the source water. The major organics found in the source water were phthalates, in addition to traces of heptadecanoic acid and higher fatty acids. The three untreated shower effluents were all similar and showed a heavy burden of fatty acids (mainly even numbered), ranging from $\mathrm{C}_{8}$ to $\mathrm{C}_{18}$, and hydrocarbons. In contrast, the treated water samples were very clean and very similar in trace organic content to that of the source water. Concentrations of individual trace organics were estimated to range from $<0.1 \mathrm{ppb}$ to $10 \mathrm{ppb}$, with the majority below $1 \mathrm{ppb}$. No new trace organics were found in the treated water samples after chlorination. The only chlorine-containing compounds found in any of the samples were shown to be impurities present in the chloroform used for liquid/liquid extraction of the trace organics. The total trace organic content of the treated waters appeared to decrease with increasing number of recycles: recycle 1 was equivalent to source water, recycle 4 was somewhat cleaner, and recycle 8 was cleaner still.

In view of these results, only two rather than three sets of samples, those from recycle 3 and recycle 11, were analyzed from batch two. A very similar pattern was observed; no new trace organics were found in the treated water samples after chlorination, and the total trace organic content appeared to decrease between recycle 3 and recycle 11 .

\footnotetext{
${ }^{5}$ Memorandum, GC/MS Analyses of Water Samples from VJCA/VMIRL Shower Water Recycling Tests (U.S. Army Medical Bioengineering Research and Development Laboratory, August 20,1985).
} 
Table 4

Measured Parameters in Wastewater, Settled, and Piltered Water-Batch 1

Sample/

Parameters Cycle 1 Cycle 2 Cycle 3 Cycle 4 Cycle 5 Cycle 6 Cycle 7 Cycle 8

Source

$\begin{array}{lc}\text { Alkalinity } & 361 * \\ \text { Tot. hard. } & 146 \\ \text { Turbidity } & 0.2 \\ \text { Res. Cl } & 0.25 \\ \text { COD } & 253 \\ \text { LAS } & 0.07 \\ \text { TDS } & 175 \\ \text { TOC } & 6.4\end{array}$

Wastewater

\begin{tabular}{lcccccccr} 
Turbidity & 370 & 155 & 61 & - & 133 & 62 & 200 & 57 \\
COD & 987 & 617 & 276 & - & 393 & 285 & 488 & \multicolumn{1}{c}{395} \\
LAS & 0.57 & 0.85 & 1 & - & 0.85 & 0.59 & 1 & 0.8 \\
TOC & 225 & 116.3 & 77.5 & - & 116.3 & 77.5 & 173.8 & 107.5 \\
pH & 7.9 & 7.7 & 6.9 & - & 6.8 & 6.9 & 7 & 6.2
\end{tabular}

Settled

\begin{tabular}{|c|c|c|c|c|c|c|c|c|}
\hline Turbidity & 10 & 9.7 & 1.02 & - & 8.43 & 8.13 & 4.95 & 5.83 \\
\hline COD & 352 & 258 & 112 & - & 215 & 243 & 170 & 347 \\
\hline $\mathrm{pH}$ & 6.6 & 5.1 & 5.5 & - & 5.3 & 5.9 & 5.6 & 5.4 \\
\hline
\end{tabular}

Filtered

$\begin{array}{lcccccrrr}\text { Alkalinity } & 271 & 236 & 131 & - & 46.5 & 350 & 64 & 65 \\ \text { Tot. hard. } & 242 & 355 & 397 & - & 426 & 398 & 496 & 431 \\ \text { Turbidity } & 1 & 1.45 & 0.19 & - & 1.44 & 0.62 & 0.81 & 0.39 \\ \text { LAS } & 0.2 & 0.05 & 0.07 & - & 0.09 & 0.05 & 0.09 & 0.06 \\ \text { TDS } & 494 & 563.57 & 1258.94 & - & 1364.97 & 829.99 & 1447.8 & 1524.33 \\ \text { TOC } & 15.5 & 15.9 & 21.3 & - & 24.5 & 24.5 & 26.3 & 26 \\ \text { pH } & 6.7 & 4.9 & 5.9 & - & - & 5.8 & 5.9 & 6.4 \\ \text { Sulfate } & 105 & 250 & 480 & - & - & - & - & -\end{array}$

Disinfect
Free Res. Cl
$0.2 \quad 0.3$
0.35
0.25
0.25
0.34
0.25
LAS
$0.02 \quad 0.03$
0.05
0.06
0.03
0.06
0.05

*Turbidity is nephelometric turbidity units (NTU); $\mathrm{pH}=\mathrm{pH}$ units; all others are parts per million (ppm). 
Table 5

Measured Parameters in Wastewater, Settled, and Filtered Water-Batch 2, Cycles 1 through 6

Sample/

Parameter

Cycle

Cycle 2

Cycle 3

Cycle 4

Cycle 5

Cycle 6

Source

Alkalinity
Tot. hard.
Turbidity
Res. Cl
COD
LAS
TDS
TOC
pH

Wastewater

$\begin{array}{lcccccc}\text { Turbidity } & 79^{*} & 139 & 725 & 467.5 & 296 & 234 \\ \text { COD } & 377.4 & 413 & 805.5 & 834 & 552 & 706 \\ \text { LAS } & 0.45 & 0.85 & 0.7 & 0.93 & 0.91 & 1.17 \\ \text { TOC } & 22.5 & 27.5 & 180 & 157.5 & 123.8 & 158.8 \\ \text { pH } & 7.4 & 7.3 & 6.9 & 7 & 6.8 & 6.7\end{array}$

Settled

$\begin{array}{lcccccc}\text { Turbidity } & 9.8 & 6.3 & 0.57 & 1.31 & 0.57 & 0.62 \\ \text { COD } & 171 & 149 & 141 & 112.8 & 125 & 334 \\ \text { pH } & 6.4 & 6.1 & 6 & 5.8 & 5.5 & 5.8\end{array}$

Filtered

$\begin{array}{lcccccr}\text { Alkalinity } & 222.68 & 120 & 158 & 58.5 & 34 & 60.3 \\ \text { Tot. hard. } & 256 & 332 & 384 & 466 & 526 & 531 \\ \text { Turbidity } & 1.24 & 0.24 & 0.12 & 0.22 & 0.10 & 0.14 \\ \text { LAS } & 0.09 & 0.03 & 0.03 & 0.08 & 0.03 & 0.07 \\ \text { TDS } & 438.20 & 640.81 & 648.69 & 1079.34 & 1279.68 & 1367.8 \\ \text { TOC } & 2.5 & 4.6 & 2.5 & 9.1 & 23 & 24.5 \\ \text { pH } & 6.6 & 5.9 & 5.8 & 6 & 5.7 & 6.2 \\ \text { Sulfate } & - & - & - & - & - & - \\ \text { COD } & - & - & - & - & 1.07 & 157\end{array}$

Disinfect
Free Res. Cl
0.30
0.24
0.04
0.2
0.2
0.2
0.3
LAS
0.04
0.03
0.05
0.04
0.04

*Turbidity is nephelometric turbidity units (NTU); $\mathrm{pH}=\mathrm{pH}$ units; all others are parts per million (ppm). 
Table 6

Measured Parameters in Wastewater, Settled, and Filtered Water--Batch 2, Cycles 7 Through 11

Sample/

Parameter

$\begin{array}{lllll}\text { Cycle } 7 & \text { Cycle } 8 & \text { Cycle } 9 & \text { Cycle } 10 & \text { Cycle } 11\end{array}$

Source

Alkalinity

Tot. hard.

Turbidity

Res. Cl

COD

LAS

TDS

TOC

$\mathrm{pH}$

Wastewater

Turbidity

COD

$285.25^{*}$

253

0.99

625

LAS

TOC

162.50

0.88

6.9

180

7

538

892

1.15

197.5

$\begin{array}{ll}285 & 369 \\ 531 . & 697\end{array}$

$\mathrm{pH}$

7

170.

0.53

172.5

$\begin{array}{ll}6.8 & 6.6\end{array}$

Settled

Turbidity

COD

1.2

2.25

1
115
5.7

9.8

274

5.9

5.7

5.5

184

5.8

5.9

5.5

5.9

Filtered

$\begin{array}{lccccc}\text { Alkalinity } & 54 & 61 & 50 & 31 & 109 \\ \text { Tot. hard. } & 528 & 523 & 544.5 & 554 & 661 \\ \text { Turbidity } & 0.14 & 0.12 & 0.21 & 1.24 & 0.16 \\ \text { L.AS } & 0.03 & 0.03 & 0.06 & 0.02 & 0.04 \\ \text { TDS } & 1490.40 & 1342.68 & 1423.79 & 1539.67 & 1682.38 \\ \text { TOC } & 24 & 28.3 & 31.9 & 32 & 31 \\ \text { pH } & 6.2 & 6.7 & 5.9 & 5.5 & 7.5 \\ \text { Sulfate } & - & - & - & - & - \\ \text { COD } & 87.3 & 133 & - & - & 133\end{array}$

Disinfect

Res. $\mathrm{Cl}$

LAS

\begin{abstract}
0.3
\end{abstract}
0.28

0.04

0.05

0.3

0.04

0.06

0.4

0.04

*Turbidity is nephelometric turbidity units (NTU); $\mathrm{pH}=\mathrm{pH}$ units; all others are parts per million (ppm). 
Table 7

Bacteriological Report

\begin{tabular}{|c|c|c|}
\hline Sample* & $\begin{array}{c}\text { Samples } \\
\text { (Positive/Total) }\end{array}$ & $\begin{array}{l}\text { Total Coliform } \\
\left(\text { MPN }^{*} / 100 \mathrm{ml}\right)\end{array}$ \\
\hline $2-4-D$ & $(0 / 5)$ & $<2.2$ \\
\hline $2-6-W$ & $(4 / 5)$ & 16 \\
\hline $\mathrm{F}$ & $(1 / 5)$ & 2.2 \\
\hline D & $(0 / 5)$ & $<2.2$ \\
\hline $2-7-W$ & $(3 / 5)$ & 9.2 \\
\hline $\mathrm{F}$ & $(0 / 5)$ & $<2.2$ \\
\hline D & $(0 / 5)$ & $<2.2$ \\
\hline $2-8-W$ & $(2 / 5)$ & 5.1 \\
\hline F & $(1 / 5)$ & 2.2 \\
\hline $\mathrm{D}$ & $(0 / 5)$ & $<2.2$ \\
\hline $2-9-W$ & $(2 / 5)$ & 5.1 \\
\hline $\mathrm{F}$ & $(0 / 5)$ & $<2.2$ \\
\hline D & $(0 / 5)$ & $<2.2$ \\
\hline $2-10-W$ & $(1 / 5)$ & 2.2 \\
\hline $\mathrm{F}$ & $(0 / 5)$ & $<2.2$ \\
\hline $\mathrm{D}$ & $(0 / 5)$ & $<2.2$ \\
\hline $2-11-W$ & $(1 / 5)$ & 2.2 \\
\hline $\mathrm{F}$ & $(0 / 5)$ & $<2.2$ \\
\hline D & $(0 / 5)$ & $<2.2$ \\
\hline
\end{tabular}




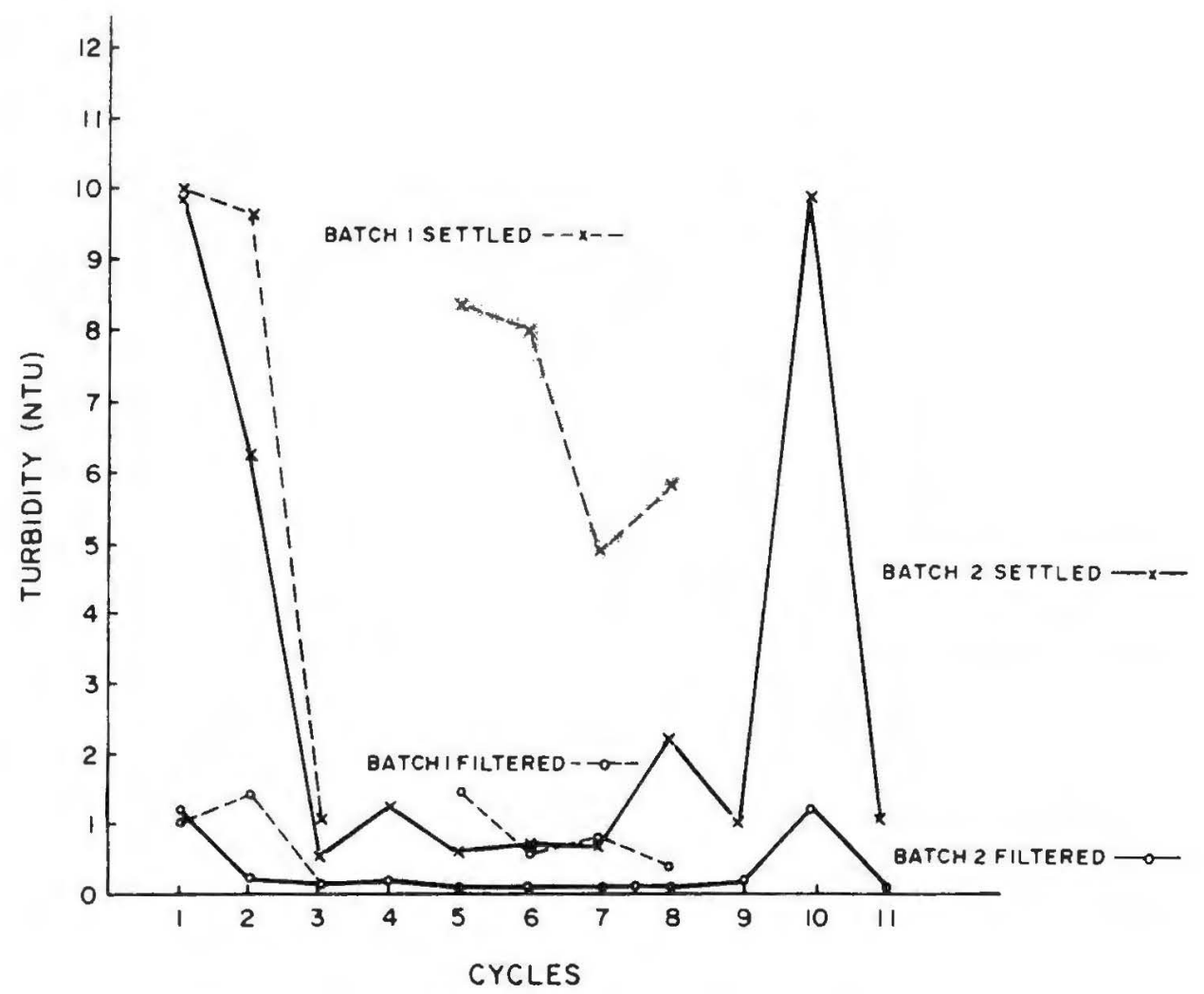

Figure 6. Turbidity (mean values - NTU).

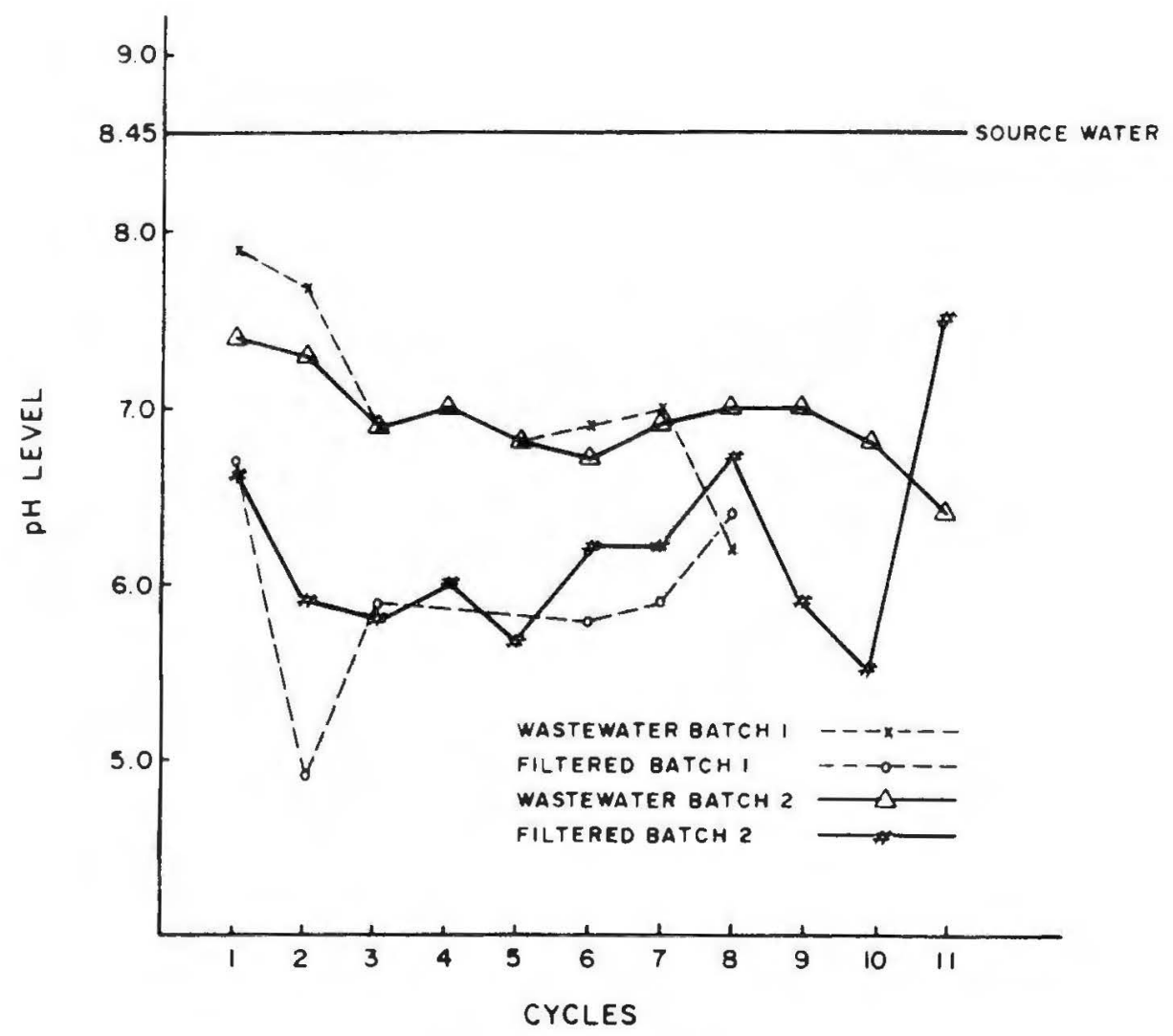

Figure 7. Mean pH. 


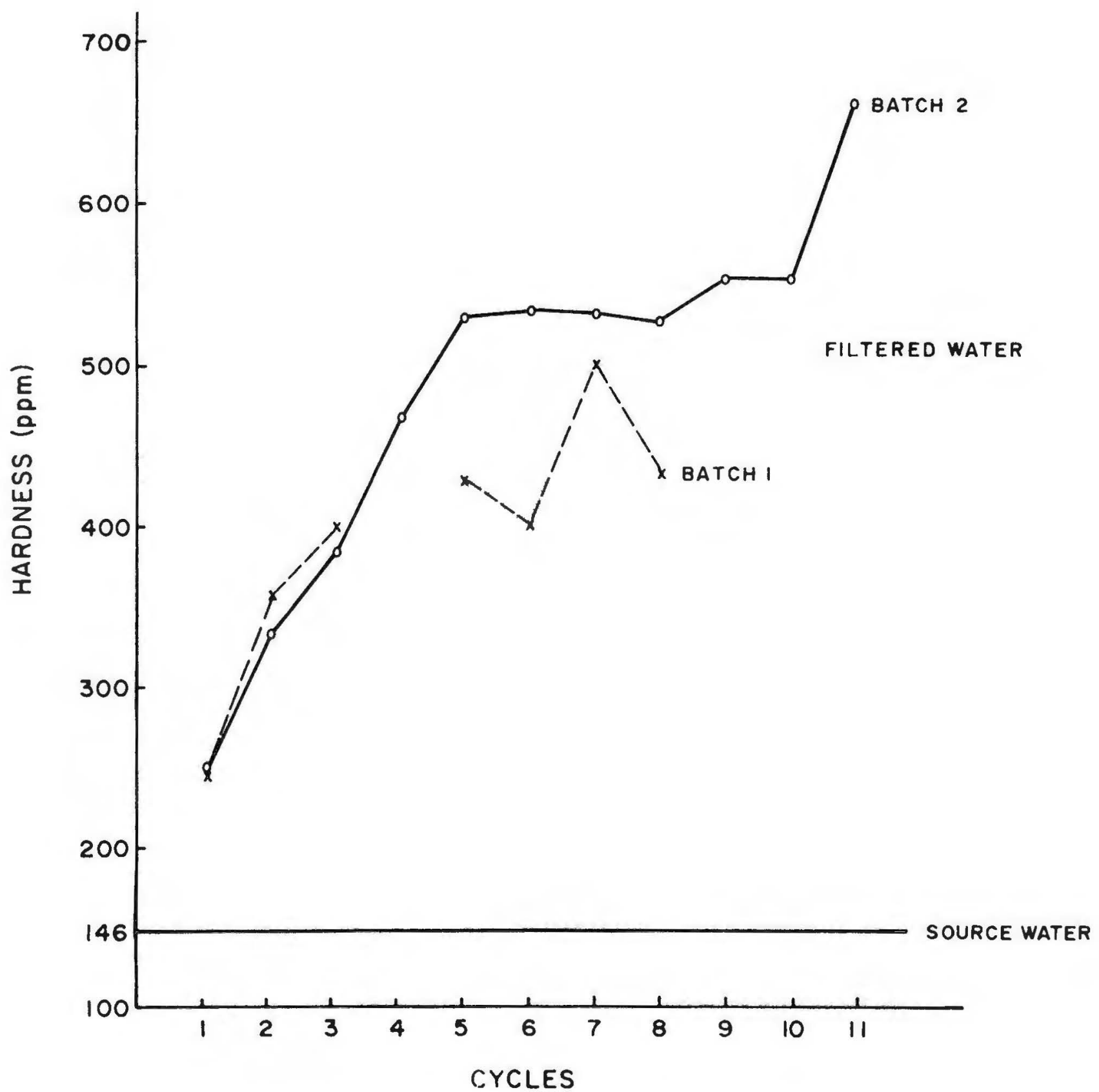

Figure 8. Hardness (mean concentration - ppm). 


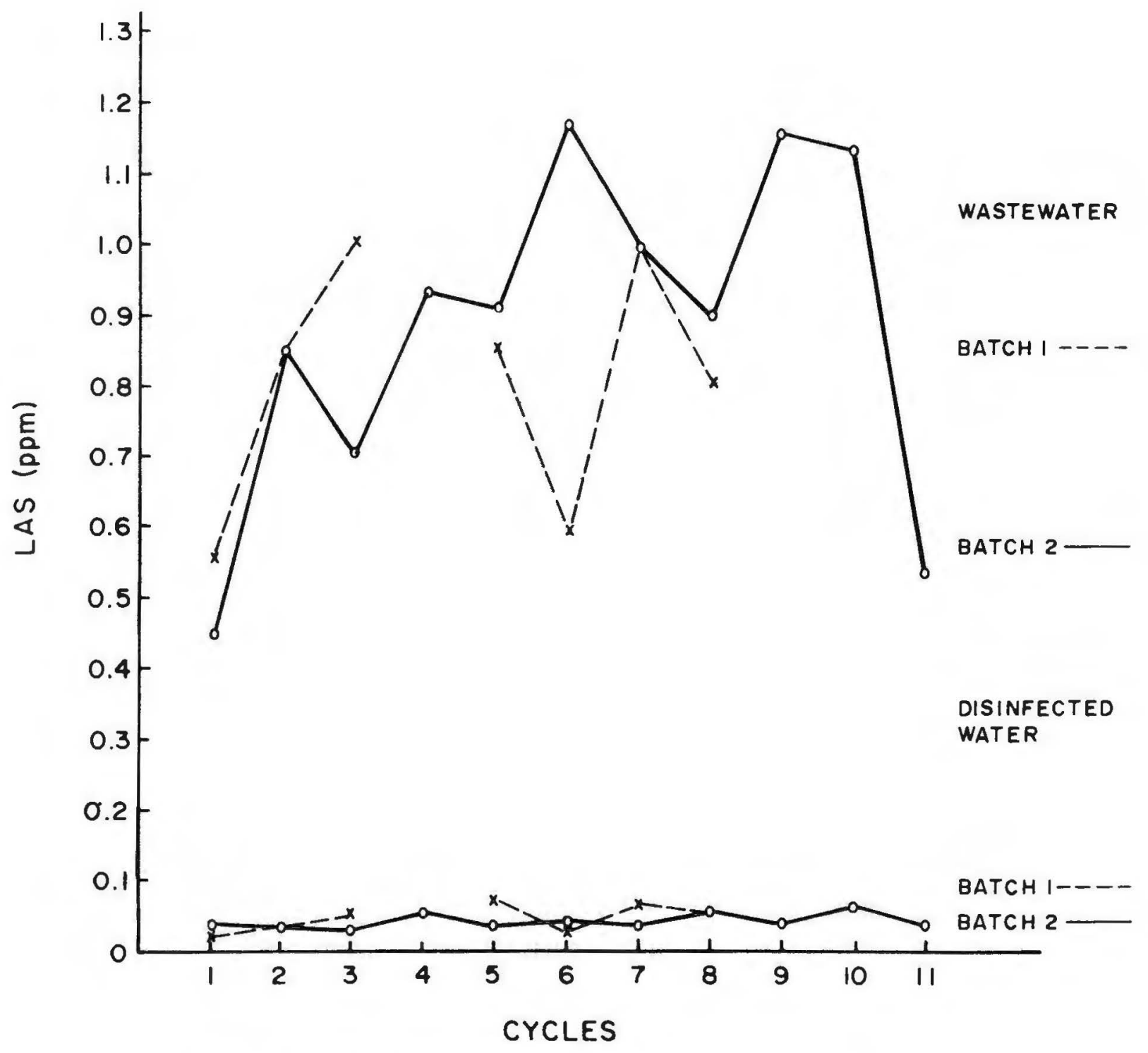

Figure 9. Linear alkyl sulfonate (mean concentration - ppm). 


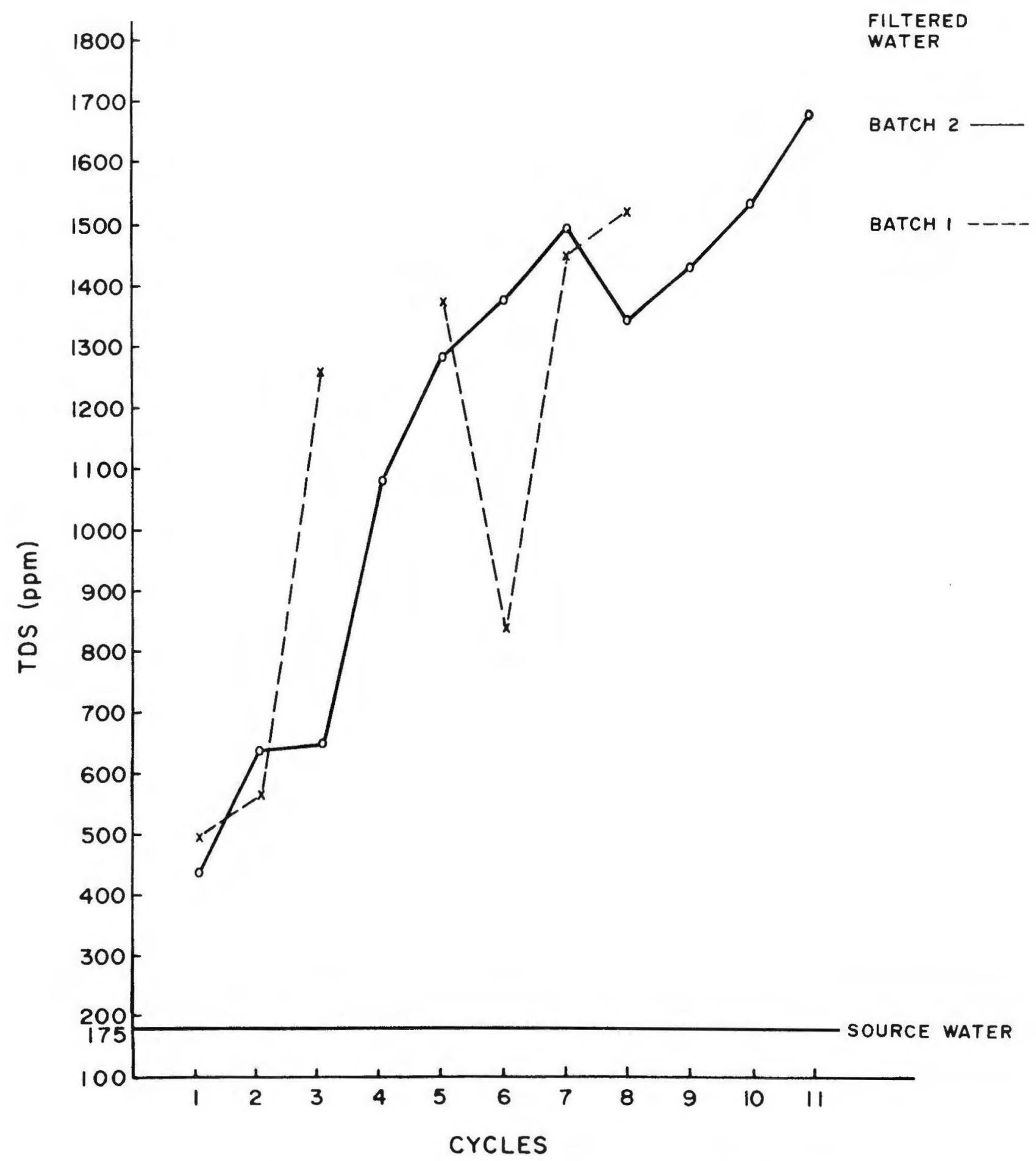

Figure 10. Total dissolved solids (mean concentration - ppm). 


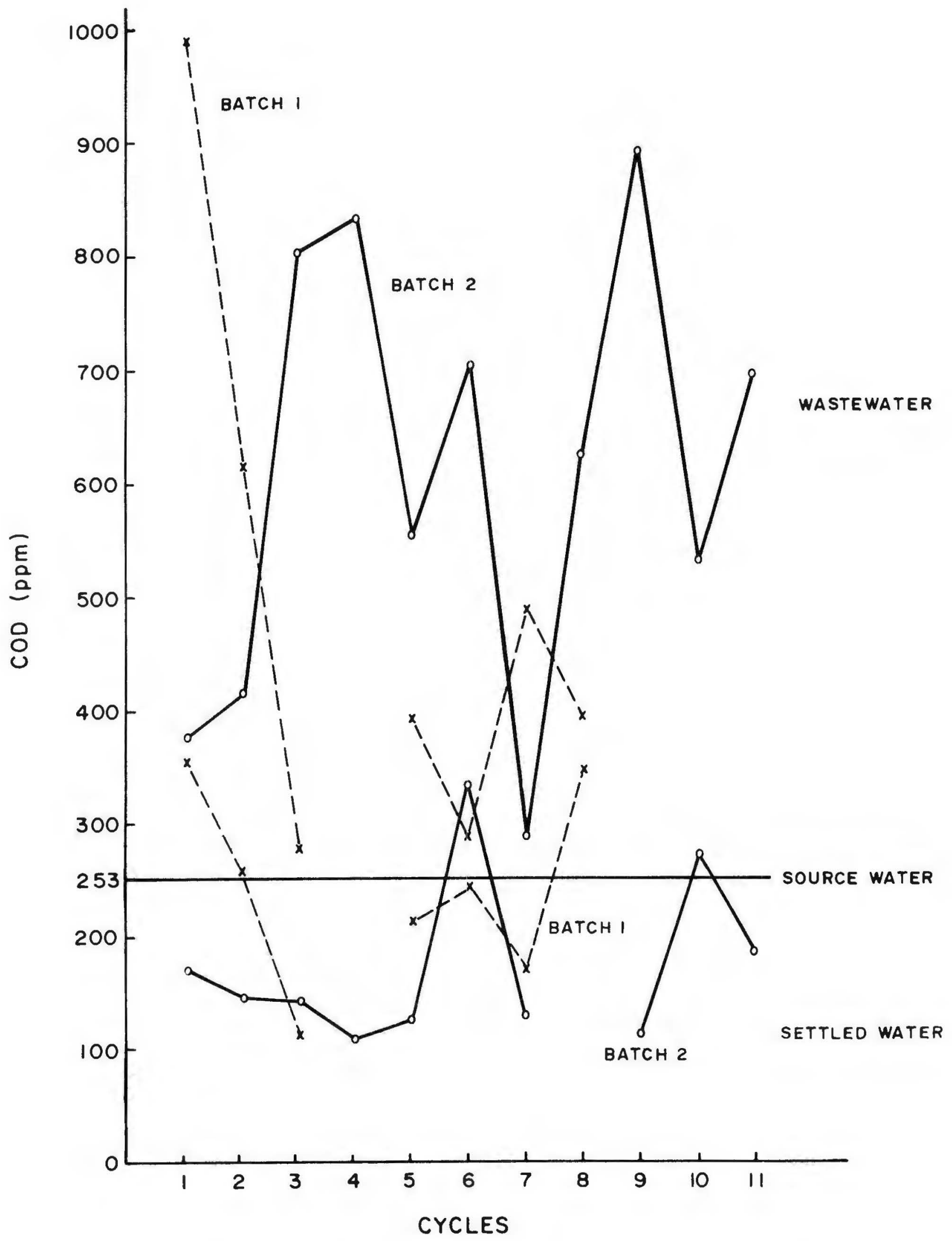

Figure 11. Chemical oxygen demand (mean concentration - ppm). 


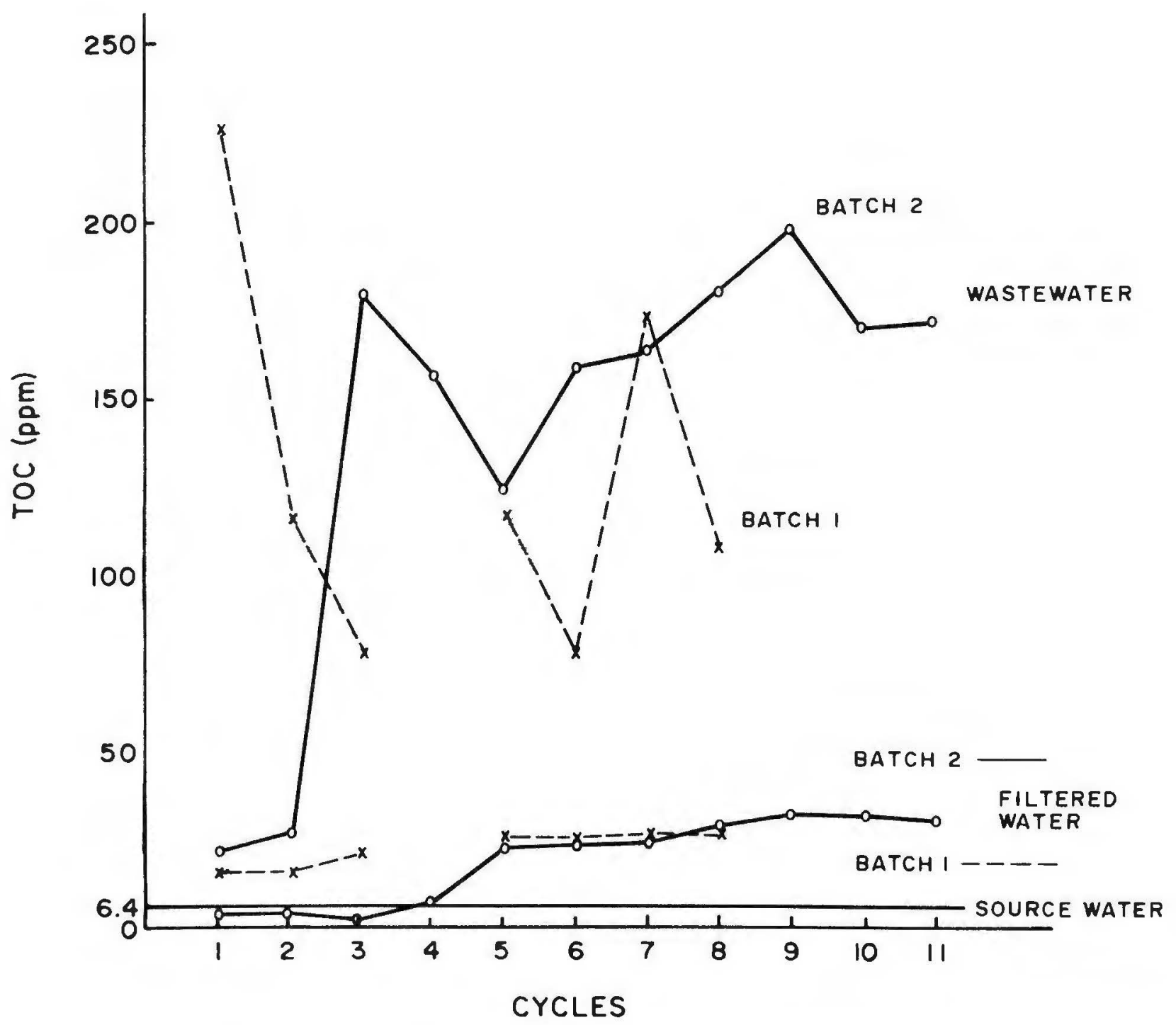

Figure 12. Total organic carbon (mean concentration - ppm). 


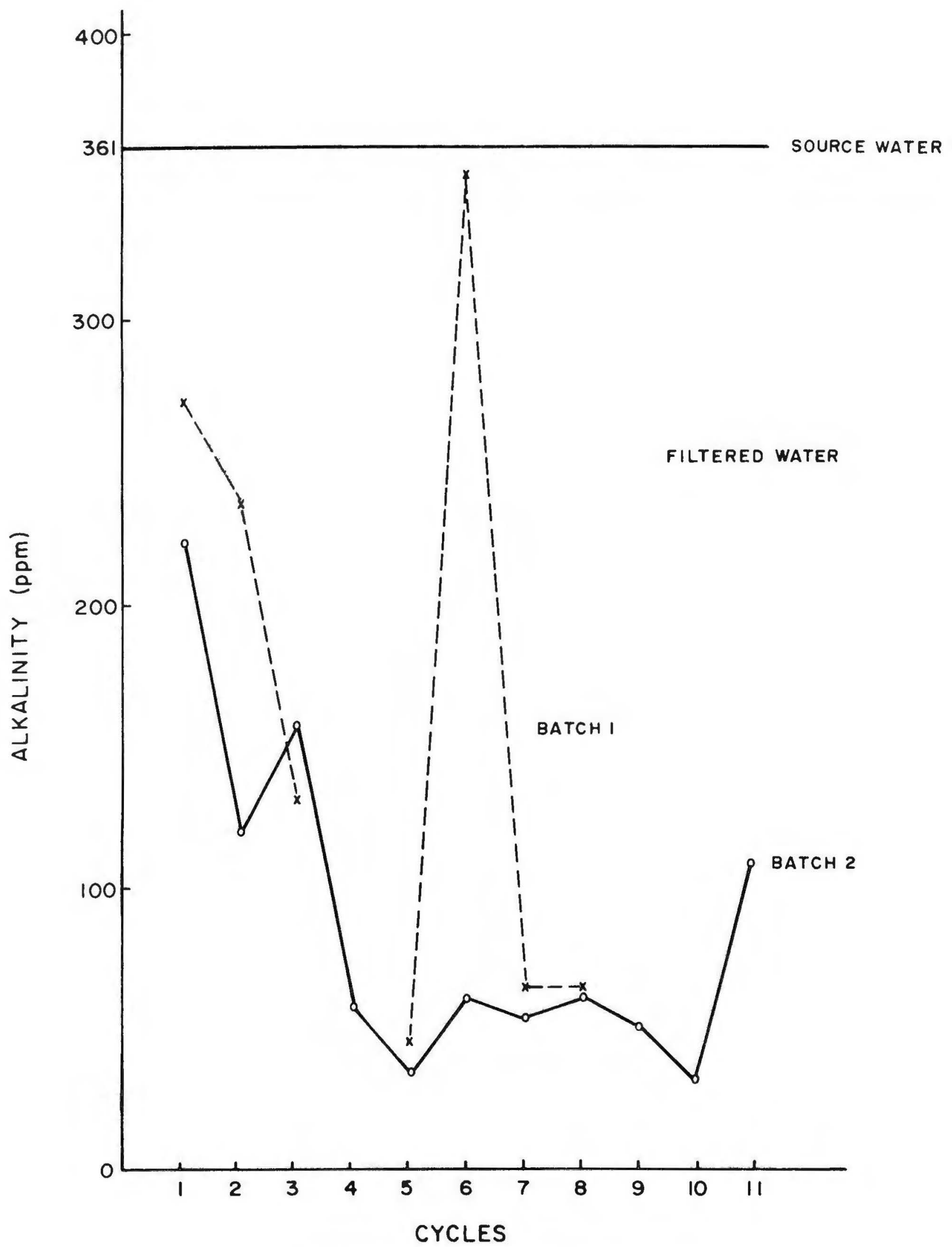

Figure 13. Alkalinity (mean concentration-ppm). 


\section{CONCLUSIONS AND RECOMMENDATIONS}

A full-scale shower wastewater recycling system has been laboratory-tested to determine if it merits further investigation and development for Army use. Based on the results of this study:

1. The batch coagulation/filtration treatment process can effectively treat shower wastewater to a quality permitting it to be recycled in military bath facilities.

2. The treatment equipment and process are compatible with conventional shower facilities (fixed and portable) when provision is made for collecting the wastewater for treatment.

3. Powdered activated carbon dosages can be reduced about 50 percent (from 6.5 lb to $3 \mathrm{lb}$ ) starting with the third cycle when enough sludge is available for resuspension in subsequent cycles.

4. The number of treatment cycles permissible on a batch of shower wastewater cannot be quantified specifically. A more appropriate indicator of when to terminate recycling is when the hardness level increases to the point at which a bather no longer obtains a satisfactory lather from the soap and shampoo being used.

5. Activated carbon is effective in removing soap, odors, and trace organics from shower wastewater.

6. Use of sulfuric acid to depress the $\mathrm{pH}$ of wastewater enough to achieve good flocculant formation and coagulation with polymers raises the sulfate level, which appears to be a major contributor to total dissolved solids buildup.

These promising results provide enough evidence to justify further investigation of the proposed shower water recycling systems in both laboratory and full-scale training exercises. Other topics requiring further invesigation include the bath water collection system and procedures. Environmental impacts of the discarded sludge and wastewater also merit investigation. 


\section{APPENDIX: \\ SHOWER TEST CONSENT FORM}

I, have voluntarily agreed to shower in a shower wastewater recycling system located in Nichols Engineering Building. Furthermore, I agree to shower in potable water immediately after showering in recycled water.

I understand that the shower water will be treated before being recycled and that the recycled water will meet the U.S. Army Office of the Surgeon General (OTSG) interim quality criteria for direct reuse. The recycled water will be treated by a combination of coagulation, filtration, and disinfection techniques.

Recent Army studies of potential measures that could be employed to reduce water usage among military units operating in a hot desert environment concluded that recycling shower wastewater could produce worthwhile savings in water usage. A preliminary estimate indicated that approximately a 75 percent reduction in water requirements would be possible by renovating shower wastewater from field bath facilities and reusing the treated water for subsequent showering. Since approximately 5000 gallons of water are required for 300 soldiers to shower, it is prudent that the Army evaluate the merits of shower wastewater recycling.

The degree of risk and discomfort is minimal in view of the fact that the chemicals used are powdered activated carbon, anionic and cationic polymers, and chlorine. The chlorine is added to the holding tank before the water is recycled.

I have the freedom to withdraw from this program at any time, without prejudice, upon notifying the project director.

The project director and/or his associates will answer any inquiries concerning the procedures at any time.

Signature

Project Director

Date 


\section{LIST OF ABBREVIATIONS}

\begin{tabular}{|c|c|}
\hline AFCS & Army Facilities Components System \\
\hline BOD & Biochemical Oxygen Demand \\
\hline $\mathrm{Cl}$ & chlorine \\
\hline COD & Chemical Oxygen Demand \\
\hline $\mathrm{CT}$ & collection tank \\
\hline $\mathrm{DE}$ & diatomaceous earth \\
\hline DPD & $\mathrm{N}, \mathrm{N}$-diethyl-p-phenylenediamine \\
\hline FWT & freshwater tank \\
\hline g & grams \\
\hline gal & gallons \\
\hline $\mathrm{gal} / \mathrm{hr}$ & gallons per hour \\
\hline $\mathrm{gal} / \mathrm{min}$ & gallons per minute \\
\hline $\mathrm{GC} / \mathrm{MS}$ & gas chromatogrphy/mass spectroscopy \\
\hline gpm & gallons per minute \\
\hline HT & holding tank \\
\hline LAS & linear alkyl sulfonate \\
\hline lb & pounds \\
\hline $\mathrm{mg}$ & milligrams \\
\hline $\mathrm{mg} / \mathrm{l}$ & milligrams per liter \\
\hline $\min$ & minutes \\
\hline $\mathrm{mL}$ & milliliters \\
\hline MPN & most probable number \\
\hline NTU & Nephelometric Turbidity Units \\
\hline OTSG & Office of the Surgeon General \\
\hline PAC & Powdered Activated Carbon \\
\hline ppm & parts per million \\
\hline psig & pounds per square inch gauge \\
\hline PVC & polyvinyl chloride \\
\hline TDS & Total Dissolved Solids \\
\hline TOC & Total Organic Carbon \\
\hline TST & treatment and settling tank \\
\hline V & volts \\
\hline VMI & Virginia Military Institute \\
\hline W & watt \\
\hline
\end{tabular}




\section{USA-CERL DISTRIBUTION}

Chief of Engineers

ATTN: Tech Monitor

ATTN: DAEN-IMS-L

ATTN: DAEN-CCP

ATTN: DAEN-CW

ATT'N: DAEN-CWE

ATTN: DAEN-CWM-R

ATTN: DAEN-CW()

ATTN: DAEN-CWP

ATTN: DAEN-EC

ATTN: DAEN-ECC

ATTN: DAFN-ECE

ATTN: DAEN-ECR

ATTN: DAEN-R1)

ATTN: DAEN-RDC

ATTN: DAEN-RDM

ATTN: DAEN-RM

ATTN: DAEN-ZCE.

ATTN: DAEN $Z \mathrm{ZC}$

ATTN: DAEN-ZCI

ATTN: DAEN-ZCM

ATTN: DAEN-ZCZ

FESA, ATTN: Library 22060 ATTN: DET III 79906

US Army Engineer Districts ATTN: Library (41)

US Army Engineer Divisions ATTN: Library (14)

US Army Europe

AEAEN-ODCS/Engr 09403

ISAE 09081

$\checkmark$ Corps

ATTN: DEH (11)

VII Corps

ATTN: DEH (15)

21 st Support Command

ATTN: DEH (12)

USA Ber!in

ATTN: DEH (11)

USASETA $F$

ATTN: DEH (10)

Allied Command kurope (ACE)

ATTN: DFH (3)

8th USA, Korea (19)

USA Japan (USARJ)
ATTN: AJEN-DEH 96343
ATTN: DEH-Honshu 96343
ATTN: DEH-(Okinawa 96331

416 th Engineer Command 60623

ATTN: Facilities Engineer

US Military Academy 10966

ATTN: Facilities Engineer

ATTN: Dept of Geography \&

Computer science

ATTN: DSCPER/MAEN-A

AMMRC, ATTN DRXMR-WE 02172

USA ARRCOM 61299

ATTN: DRCIS-RI!

ATTN: DRSAR IS

A MC - Dir., Inst., \& Servc

ATTN: DEH (23)

DLA ATTN: DLA WI 22314

DNA ATTN: NADS 20305

FORSCOM

FORSCOM Engr, ATTN: AFEN-DEH

ATTN: DEH (23)

HSC

ATTN: HSLO F 78234

ATTN: Facilities Engineer Fitssimons AMC 80240 Walter Reed A.MC 20012

[NSCOM - Ch, Inst]. Div

ATTN: Eacilities Engineer (3)
ROK/US Combined Forces Command 96301

ATTN: EUSA-HHC-CFC/Engr

MDW, ATTN: DEH (3)

MTMC

ATTN: MTMC-SA 20315

ATTN: Facilities Engineer (3)

NARADCOM, ATTN: DRDNA-F 01760

TARCOM, Fac. Div. 48090

TRADOC

HQ, TRADOC, ATTN: ATEN-DEH

ATTN: DEH (19)

TSARCOM, ATTN: STSAS-F 63120

USACC, ATTN: Facilities Engr (2)

WFSTCOM

ATTN: DFH, Ft. Shafter 96858

ATTN: APEN-IM

SHAPE 09055

ATTN: Surv. Section, CCB-OPS

Infrastructure Branch, LANDA

HQ USE.UCOM 09128

ATTN: ECJ 4/7-LOE

FORT BELVOIR, VA 22060 (7)

ATTN: Canadian Liaison Officer

ATTN: British Liaison Officer

ATTN: Australian Liaison Officer

ATTN: French Liaison Officer

ATTN: German Liaison Officer

ATTN: Water Resources Support Ctr

ATTN: Engr Studies Center

ATTN: Engr Topographic Lab.

ATTN: ATZA-DTE-SU

ATTN: ATZA-DTE-EM

ATTN: R\&D Commend

CRREL, ATTN: Library 03755

WES, ATTN: Library 39180

HQ, XVIII Airborn Corps

and Fort Bragg

ATTN: AFZA-FE-EE 28307

Area Engineer, AEDC-Area Office

Arnold Air Force Station, TN 37389

Chanute AFB, IL, 61868

3345 CES/DE, Stop 27

Norton AFB, CA 92409

ATTN: AFRCE-MX/DEE

AFESC, Tyndall AFB, EL 32403

NAVFAC

ATTN: Engineering Command (7)

ATTN: Division Offices (6)

ATTN: Naval Public Works Center (9)

ATTN: Naval Civil Engr lab. (3)

ATTN: Library, Code L08A NCEL 93043

Defense Technical Info. Center 22314 ATTN: DDA

(2)

Engr Societies Library, NY 1001 ?

Natl Guard Bureau instl. Div 20310

US Govt Print Office 22304

Receiving Sect/Depository Copies (2)

US Army Env. Hygiene Agency

ATTN: HSHB-E 21010

National Bureau of Standards 20899 
Chief of Engineers

ATTN: DAEN-ZCF-B

ATTN: DAEN-2CF-U

ATTN: DAEN-ECZ-A

US Army Engineer District New York 1000 ?

ATTN: Chief, NANEN-E

ATTN: Chief, Design Br.

Pitcsburgh 15222

ATTN: Chief, Engr Div

Philsdelphi 19106

ATTN: Chief, NAPEN-E

Norfolk 23510

ATTN: Chief, NAOEN-D

Huntington 25721

ATTN: Chief, ORHED-H

Hinington 28401

ATTN: Chief, SAWEN-PM

ATTN: Chief, SAWEN-E

Charleston 29402

ATTN: Chief, Engr Div

Savannah 31402

ATTN: Chief, SASAS-L

Jacksonville 32232

ATTN: Env Res Br

Mobile 36628

ATTN: Chief, SAMEN-C

Vicksburs 39180

ATTN: Chief, Engr Div

Louiguille 4020 l

ATTN: Chief, Engr Div

St. Paul 55101

ATTN: Chief, ED-H

Chics 800604

ATTN: Chief, NCCCO-R

ATTN: Chief, NCCED-H

ATTN: Chief, NCCPD-ER

ATTN: Chief, NCCPE-PES

$S t$. Louis 63101

ATTN: Chief, ED-B

ATTN: Chief, ED-D

Kansas City 64106

ATTN: Chief, Engr Div

Omaha 68102

ATTN: Chief, Engr Div

Lictle Rock 72203

ATTN: Chief, Engr Div

Tulsa 74102

ATTN: Chief, Engr Diy

Fort worth 76102

ATTN: Chief, SWPED-D

ATTN: Chief, SWFED-MA/MR

Calveston 77550

ATTN: Chief, SHGAS-L

ATTN: Chief, SUCCO-M

Los Angeles 90053

ATTN: Chief, SPLED-E

San Francisco 94105

ATTN: Chief, Engr Div

Sacramento 95814

ATTN: Chief, SPKED-D

Far East 96301

ATTN: Chief, Engr Div

Seatcle 98124

ATTN: Chief, NPSEN-FM

ATTN: Chief, EN-DB-SE

ATTN: Chief, NPSEN-PL-WC

ATTN: Chiet, NPSEN-PL-ER

Walla Walla 99362

ATTN: Chief, Engr Div

Alask 9950l

ATTN: Chief, NPASA-R

US Army Engineer Division New England 02154

ATTN: Chief, NADEN-I

North Atlentic 10007

ATTN: Chief, NADEN-T

Middle East (Rear) 22601

ATTN: Chief, MEDED-T

South Atlantic 30303

ATTN: Chief, SADEN-TE
US Army Engineer Division

Huntsuille 35807

ATIN: Chief, HNDED-ME

ATTN: Chief, HNDED-SR

ATTN: Chief, PD-R

Ohio River 45201

ATTN: Chief, Engr Div

North Central 6060s

ATTN: Chief, Engr Planning Br

Missouri River 68101

ATTN: Chief, MRDED-T

Southwestern 75242

ATTN: Chief, SWDED-TH

North Pacific 97208

ATTN: Chiof, Engr Div.

South Pacific 94111

ATTN: Chief, SPDED-TC

ATTN: Laboratory

Pacific Ocean 96858

ATTN: Chief, Engr Div

ATTN: Chief, PODED-MP

ATTN: Chief, PODED-P

Sth US Army 78234

ATTN: AFKB-LC-E

6th US Army 94129

ATTN: AFKC-EN

7 th US Army 09407

ATTN: AETTM-HRD-EHD

10th Medical Laboratory

APO NEW YORK 09180
ATTN: Chief, HNDED-CS

Lower Mississippi Valley 39180

Boll ing AFB, DC 20330 AP/LEEEU

Litcle Rock APB

ATTN: $314 /$ DEEE

Patrick API, PL 32925

ATIN: XRQ

Tinker APB, OK 73145

2854 ABG/DEEE

Tyndal1 APB, FL 32403

APESC/PRT

Bldg Research Advisory soard 20418

Dept of Transportation

Talahasee, FL 32304

Dept of Transportation Library 20590

Transportation Research Board 20418

Airports and Construction Services Dir Ottawa, Oncario, Canada KIA ON8

Divition of Building Research

Otriva, Ontario, Canada KLA OR6

National Defense Headquarters

Ottaue, Onterio, Canada K1A OK2

US Army Foreign Science \& Tech Center

ATTN: Charlottesville, VA 22901

ATTN: Far East Office 96328

USA ARRADCOM

ATTN: DRDAR-LCA-OK 07801

West Point, NY 10996

ATTN: Dept of Mechanics

ATTN: Library

Ft. Belvoir, VA 22060

ATTN: Learning Resources Center

ATTN: ATSE-TD-TL (2)

Pt. Clayton Conal Zone 34004

ATTN: DFAE

Ft. A. P. Hill 24502

ATTN: $F E$

Fr. Leavenworth, KS 66027

ATTN: ATZLCA-SA

Ft. Lee, VA 23801

ATTN: DRXMC-D (2)

Ft. MePherson, GA 30330

ATTN: AFEN-CD

Ft, Monroe, VA 23651

ATTN: ATEN-AD (3)

ATTN: ATEN-FE-E

ATTN : ATEN-FE-U

Aberdeen Proving Ground, MD 21005

ATTN: ANXHE

ATTN: $\quad$ HSE-EW

ATTN: OAC-ARI I E

Naval Facilicies Engr Command 22332

ATTN: Code 04

US Naval Oceanographic Office 39522

ATTN: Library

Naval Training Equipment Center 32813

ATTN: Technical Library 


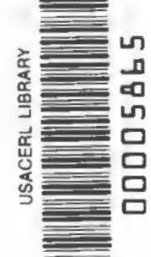




\section{DEPARTMENT OF THE ARMY}

CONSTRUCTION ENGINEERING RESEARCH LA8ORATORY CORPS OF ENGINEERS

P.O. BOX 4005

CHAMPAIGN, ILLINOIS 61820

OFFICIAL BUSINESS

PENALTY FOR PRIVATE USE $\$ 300$
BULK RATE

POSTAGE AND FEES PAID

DEPARTMENT OF THE ARMY

PERMIT NO. G.5 